\title{
Revision of Dendraena pinnatilobata Němejc from the Pennsylvanian of the Czech Republic
}

\author{
JANA FROJdOVÁ, JOSEF PŠENIČKA, JIŘí BEK \& KAREL MARTíNEK
}

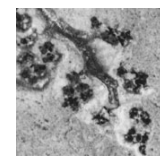

\begin{abstract}
Dendraena pinnatilobata Němejc is a Pennsylvanian true fern, which is known from the Stradonice locality (Czech Republic) only. All specimens of Dendraena pinnatilobata are preserved as three-dimensionally in volcaniclastic of Whestone Horizon (Radnice Member, Kladno Formation). Revision of this species includes detail study of pinnae and pinnules morphology, sporangia, in situ spores and a rachial anatomy. Combination of several methods was used including camera lucida, maceration of sporangial/spores, SEM observation and cross sections of rachides for precise description of this species. D. pinnatilobata pinnae were borne on the rachides of the Anachoropteris robusta-type anatomy. This real organic connection between pinnae/pinnules (including reproductive organs) and rachial anatomy is rare in fossil record. This knowledge is very important for understanding of a leptosporangiate fern evolution. Sporangia of Dendraena pinnatilobata are annulate with band-lateral-upper type of annulus and in situ spores of the Microreticulatisporites harrisonii type, described for the first time, are unique for D. pinnatilobata. Based on this type of sporangia the species belongs to the leptosporangiate ferns. According to the petrological and sedimentological study of host sediments it is possible to infer that specimens of Dendraena were transported a short distance. Transport was very fast and fossils were deposited in supercritical conditions, which resulted in rapid burial of the plants and their excellent preservation. The plant host rock - Whetstone Horizon - also contains abundant volcaniclastic components. D. pinnatilobata grew in close proximity to the riverside or the peatland margins. - Key words: Dendraena, Anachoropteris, fern, Pennsylvanian, in situ spores.
\end{abstract}

FrojdovÁ, J., PŠEnIČKA, J., BEK J. \& MARTíneK, K. 2017. Revision of Dendraena pinnatilobata Němejc from the Pennsylvanian of the Czech Republic. Bulletin of Geosciences 92(1), 75-94 (13 figures, 2 tables). Czech Geological Survey, Prague. ISSN 1214-1119. Manuscript received August 12, 2016; accepted in revised form March 7, 2017; published online March 31, 2017; issued March 31, 2017.

Jana Frojdová \& Jiři Bek, Laboratory of Palaeobiology and Palaeoecology, Institute of Geology of the Czech Academy of Sciences, v.v.i., Rozvojová 269,16500 Prague 6, Czech Republic; frojdova@gli.cas.cz, bek@gli.cas.cz・Josef Pšenička, Centre of Palaeobiodiversity, West Bohemian Museum in Pilsen, Kopeckého sady 2, Pilsen, 301 00, Czech Republic; jpsenicka@zcm.cz•Jana Frojdová \& Karel Martínek, Institute of Geology and Palaeontology, Charles University, Faculty of Science, Albertov 6, 12843 Prague 2, Czech Republic; karel.martinek@natur.cuni.cz.

The leptosporangiate ferns (filicalean) are known from the Mississippian (Taylor et al. 2009) and they are widespread on nearly all Carboniferous localities through the world. According to Rothwell (1987) the abundant of filicalean increased in Pennsylvanian age. Many features of modern ferns, as one cell layer of the sporangial wall with a distinct annulus, or rachial anatomy, evolved independently more than once in several families (Galtier \& Phillips 1996). Generally, filicaleans became members of plant communities in a broad array of habitats and clearly showed a vast array of ecological roles in the Carboniferous biotopes (DiMichele \& Phillips 2002; Galtier \& Phillips 2014). The specimens of Dendraena pinnatilobata (Němejc) obtained from a volcaniclastic deposit provide a better understanding of the palaeo-environment in which the leptosporangiate ferns grew. Dendraena pinnatilobata was established by
Němejc (1934) based on material from Feistmantel's, 1868 collection, which come from Stradonice locality (near Beroun). The locality is situated in small tectonically bounded Lísek relict of Duckmantian coal-bearing strata (Radnice Member, Kladno Formation). Němejc (1934) reidentified Feistmantel's, 1868 unpublished specimens as Dendraena pinnatilobata beside original Feistmantel's identification Oligocarpia sp. (notice on specimen label). Němejc (1934) characterised D. pinnatilobata as a fern with sphenopterid pinnules bearing groups of sessile, annulate sporangia with an oblique or asymmetric annulus and distinguished only two types of sporangial cells. The first type of cells represents the annulus and the second is typified by narrow and elongated cells, which probably represent stomium. Unfortunately, Němejc (1934) did not macerate specimens, i.e., he could not recognize all the types and the extension of 
sporangium cells. Němejc (1934) mentioned a close similarity between Dendraena pinnatilobata, Sturia amoena Němejc and Boweria Kidston; but emphasised the differentiation of Dendraena from Boweria Kidston, Chansitheca Regè, Discopteris Stur, Hymenophyllites Goeppert, Kidstonia Zeiller, Oligocarpia Goeppert, Pteridotheca Scott, Senftenberia Corda, Sturiella Weiss and Todeopsis Renault.

Combination of several techniques were used for a precise classification of plant remains, including camera lucida drawings, transverse sections of rachides, sporangial cell composition, in situ spores and a characterisation of the sedimentary environment, including petrological analysis (e.g. electron microprobe and X-ray diffraction analyses). All data that were obtained using the above mentioned methods provide us information for precise classification. Petrological analyses were carried out to understand the composition and origin of the whitish rim surrounding this ferns. Petrology and sedimentology also contributed to determining the length of the transport of the plant fossils and an interpretation of the palaeoenvironment.

\section{Material and methods}

The review is based on Němejc's (respectively Feistmantel's) type collection consisting of 28 fertile specimens, from the Stradonice locality (Lískov outlier near Beroun; Pešek \& Martínek 2012) southeast part of the Kladno-Rakovník Basin (Czech Republic). Specimens are stored in the National Museum, Prague, Czech Republic. All specimens come from volcaniclastic material (probably from the Whetstone Horizon), Radnice Member, Middle Moscovian (Duckmantian; Opluštil et al. 2016). Specimens are preserved in grey laminated siltstone to claystone and are often strongly weathered and limonitised. Destructive and non-destructive methods were used to study the specimens. Scanning electron microscope (low-vacuum SEM, Hitachi S-3700N) was used as a non-destructive method for observing plant morphology. Selected specimens were drawn using camera lucida equipment (attached to a binocular microscope OLYMPUS SZX12). The non-destructive method resulted in a precise description of pinnule morphology, including the attachment pattern of the sporangium. Specimens E 4946, E 4956, E 4962 and E 7110 were macerated (destructive method) and studied in detail the structure of the sporangial cell wall and in situ spores. The sporangia were isolated from the rock matrix using 35\% hydrofluoric acid for 24 hours, and then were washed in distilled water. After this step some sporangia were selected and examined under several SEMs including Tescan VEGA3 XMU (Institute of Geology of the Czech Academy of Sciences, v.v.i., Prague), JEOL 6380LV (Institute of Geology and Palaeonto- logy, Faculty of Sciences, Charles University), and Hitachi S-3700N (National Museum, Prague). Other sporangia were macerated in Schulze's solution (Schulze 1855, Frojdová et al. 2017), washed in water and subsequently percolated with potassium hydroxide $(10 \%)$ to remove oxidation products, and washed again in water. Macerated sporangia with in situ spores were observed under SEM (Tescan VEGA3 XMU and JEOL 6380LV). Rachides of Dendraena pinnatilobata from specimens E 4955 and E 4970 were mechanically selected from specimens, fixed in a resin, cutting (cross section), fixed on glass slides and subsequently polishing on DISCOPLAN-TS. Thin sections with rachides were examined under biological microscope OLYMPUS BX51.

All digital photos of the sporangia and in situ spores are housed in the Institute of Geology of the Czech Academy of Sciences, v.v.i., Prague (Czech Republic) and in the National Museum in Prague (Czech Republic). SEM tubes with sporangia, slides and a thin section are stored in the National Museum in Prague.

The terminology for describing the pinnae/pinnules and reproductive organs comes from Frojdová et al. (2017). Descriptive terms for the spores follow the latest edition of the Glossary of Pollen and Spore Terminology (Punt et al. 2007). Spores are classified according to the system of dispersed spores suggested by Potonié \& Kremp (1954, 1955), Dettmann (1963) and Smith \& Butterworth (1967). In situ spores were compared directly with the original diagnoses, type specimens, descriptions, and illustrations of dispersed spore species. Species determinations are based solely on the original diagnoses, and not on the interpretations of subsequent authors.

Nine rock hand specimens were used (National Museum, Prague, catalogue Nos E 4950, E 4956, E 4959, E 4963, E 4964, E 4965, E 4966, E 4968 and E 4969) for petrological and mineralogical study. Two polished thin sections were used for transmission light microscopy to examine the host rock - Whetstone Horizon and the composition of the whitish rim around the plant remains. The composition and microstructures were studied using standard petrological optical microscopy in transmitted light with semiquantitative estimates of each component. Pyrite occurrence was checked by reflected light. An electron microprobe was used to understand the mineralogy and microstructures of the host rock Whetstone Horizon (24 analyses) and the whitish rim around the plant remains (57 analyses).

An X-ray powder diffraction investigation of one whetstone sample was carried out with a Bruker D8 Discover diffractometer (analyst A. Kallistová, Department of Analytical Methods, Institute of Geology of the Czech Academy of Sciences, v.v.i.) equipped with a silicon-strip linear LynxEye detector and a germanium primary monochromator providing $\mathrm{Cu} K_{\alpha l}$ radiation $(\lambda=1.54056 \AA)$. Data were collected in the $2 \Theta$ range of $3-70^{\circ}$ with a step size of 0.017 

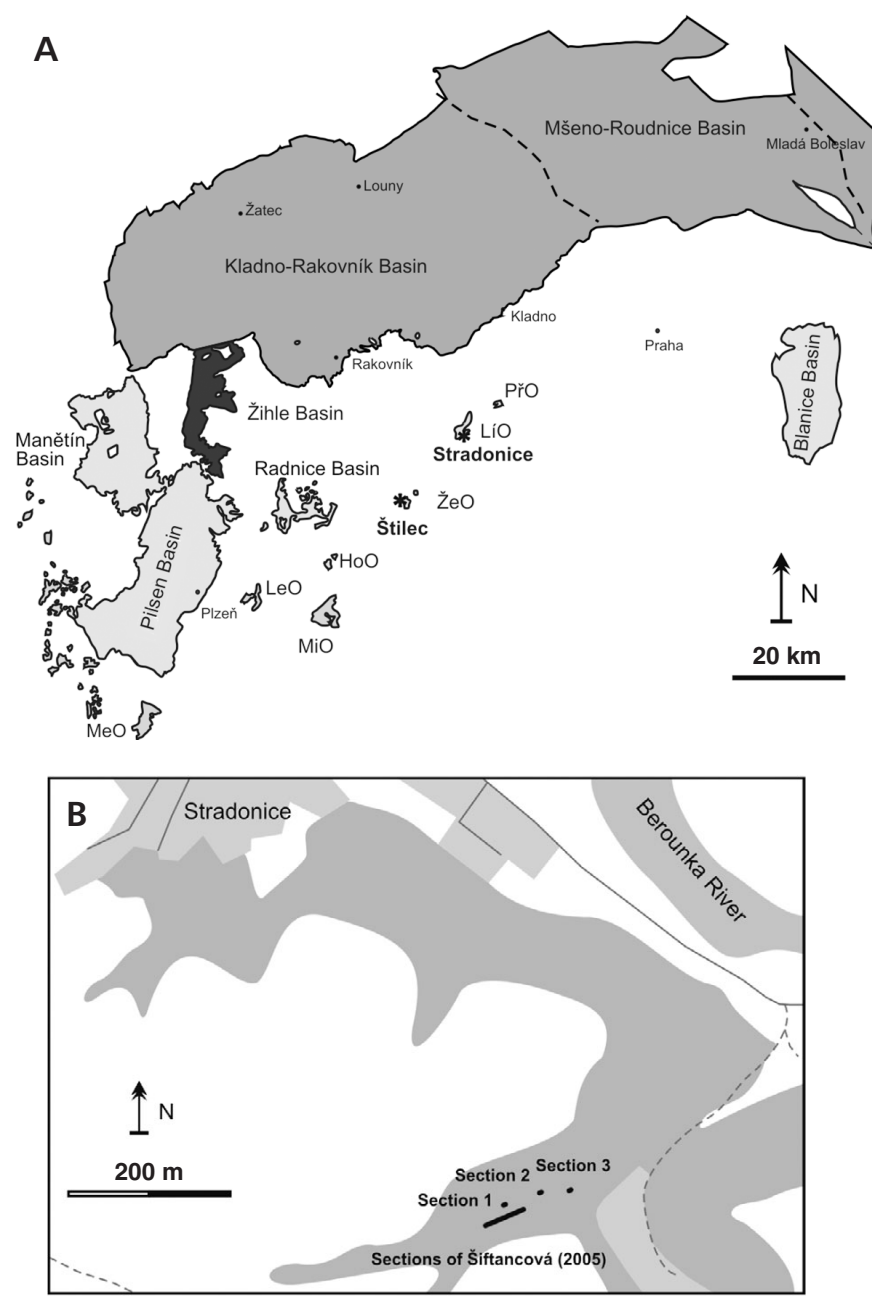

Figure 1. A - map of occurrence of studied specimens. Outliers: PřO - Malé Př́lepy, LíO - Lískov and Hýskov, ŽeO - Žebrák, $\mathrm{HoO}$ - Holoubkov, MiO - Mirošov, LeO - Letkov, $\mathrm{MeO}$ - Merklín. Studied localities: Stradonice and Štilec. $\bullet$ B - location of studied sections. Dark grey - forest, light grey - village.

and a counting time of 1 second at each step. The phase analysis was performed with the analytical computer program Diffract.

\section{Geological setting}

According to Otokar and Karel Feistmantel (in Němejc 1930), the Stradonice locality is part of the Lísek outlier, near Beroun, southeast of the Kladno-Rakovník Basin (Fig. 1A). The complete stratigraphic section of this outlier is unknown (Němejc 1930, Stárková et al. 2016). The plant assemblage of the Lísek outlier is correlative with that of the Lower Radnice Member (Němejc 1930). This author also distinguished in the Stradonice area three lithological units. The lower unit consists of fossiliferous (occurrence of Dendraena pinnatilobata) Whetstone Horizon and the
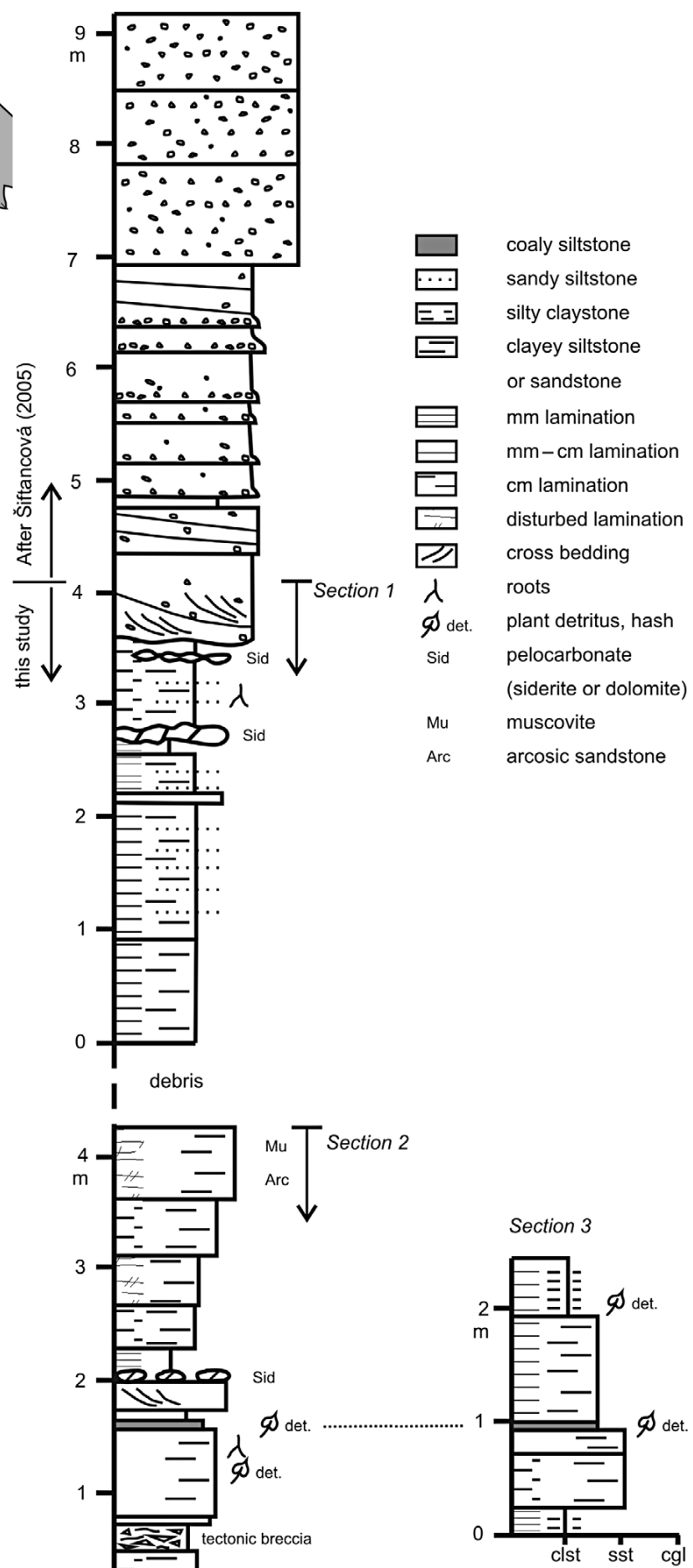

Figure 2. Measured sections in the northern valley (sensu Siftancová 2005) near Stradonice. For discussion see text.

associated fine-grained deposits interbedded in coarsegrained sandstone and conglomerate. The upper part of the lower unit is formed by fossiliferous sandstones and sandy 


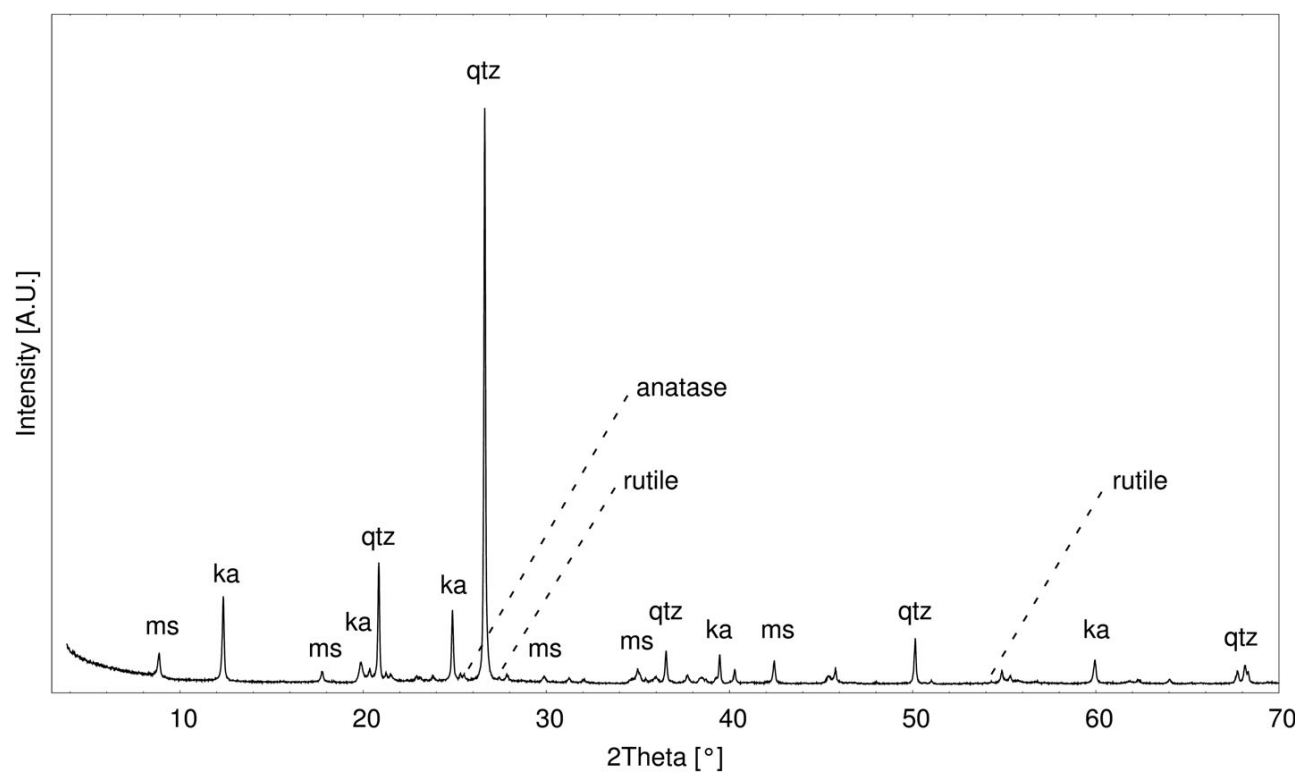

Figure 3. XRD patterns of Whetstone. Abbreviations: qtz quartz, ms - muscovite, ka kaolinite. From lectotype.

mudstones. The fossiliferous middle unit consists of coal locally called "Na Lísku Seam", which is correlated by Němejc (1930) and Pešek (2001) with the Upper Radnice Coal. The coal is overlain by grey to black mudstones and claystones. The upper unit is formed by a thick succession of fine-grained sandstones. The position of the Whetstone Horizon underneath the "Na Lísku Seam" suggests, that volcanic ash may have had a fertilising effect on the peat by providing nutrients essential for plant growth (Triplehorn et al. 1991) thus contributing to the development of the coal.

The overlying succession consists mainly of conglomerates with minor sandstones and coaly siltstones interpreted as alluvial fan deposits prograding to fluvial and floodplain deposits (Šiftancová 2005). The succession of the Radnice member strata in the Stradonice area is interpreted as a fill of tectonically active river valley margin (Šiftancová 2005), representing a high-gradient sedimentary system with a high sedimentation rate. The fine-grained fossiliferous succession composed of the "Na Lísku Seam" and Whetstone Horizon is overlaid by thick (at least $c a 35 \mathrm{~m}$ thick) succession of conglomerates (Němejc 1930).

Šiftancová (2005) studied the conglomerates and underlying sandstones in several localities near Stradonice. We add three new measured sections (Fig. 1B) of the underlying succession, which consists of finer grained depos- its in the northern valley, where Němejc (1930, 1953a) described abundant flora in volcaniclastic type of deposits (Fig. 2). In an $8 \mathrm{~m}$ thick heterolithic deposit of grey silty claystones and clayey siltstones interbedded with sandstones one thin carbonaceous siltstone is present. Rocks are laminated to discontinuously laminated and interbedded with several zones of roots and plant detritus. Two important zones with roots penetrated through strata indicate two episodes of vegetation development (Fig. 2). First zone is situated under several centimetres thick bed of coal siltstone, which represent short episode of vegetation development. Only several millimetres sized plant detritus was discovered in root zone as well as in coal siltstone. Large parts of fossil plants were not found. Second zone is underlying sandstones and represent roots, which penetrated laminated clayey siltstone and sandstones (Fig. 2). The fossil remains of overground part of plants are not present in this part of section and therefore we can speculate only that the fossiliferous strata or coal situated above this root zone was eroded by sedimentation of sandstones. Exact stratigraphic position of Němejc's (1930, 1953a) findings was not found. Generally, all deposits underlying sandstones and conglomerates could have been deposited on floodplain close to the river and/or close to the peatland in system of tectonically established valley (Opluštil 2005).

Figure 4. Fertile specimens of Dendraena pinnatilobata. All specimens stored in National Museum in Prague, Czech Republic, Němejc's collection. All specimens are from locality Stradonice, near Beroun, Radnice coal group, Moscovian. • A - part of penultimate pinnae from lectotype E 4945, scale bar $10 \mathrm{~mm}$. B - part of antepenultimate pinnae E 4962 with well-preserved fertile pinnules, scale bar 3 mm. $\bullet \mathrm{C}-$ detail of ultimate pinnae with fertile pinnules of $\mathrm{E} 4945$ immersed in alcohol; sporangia are situated near the margin in the lobe, scale bar $1 \mathrm{~mm}$. $\bullet \mathrm{D}-$ detail of fertile pinnules with midvein and lateral vein with grouped sporangia which covered all of pinnule of E 4961 immersed in alcohol, scale bar $1 \mathrm{~mm}$. $\bullet$ E - detail of fertile pinnules with midvein and lateral vein with grouped sporangia which covered all of pinnule of E 4962 immersed in alcohol, scale bar 1 mm. $\bullet$ F - detail of fertile pinnules with midvein and lateral vein with grouped sporangia which covered all of pinnule of E 4945 immersed in alcohol, scale bar 1 mm. 

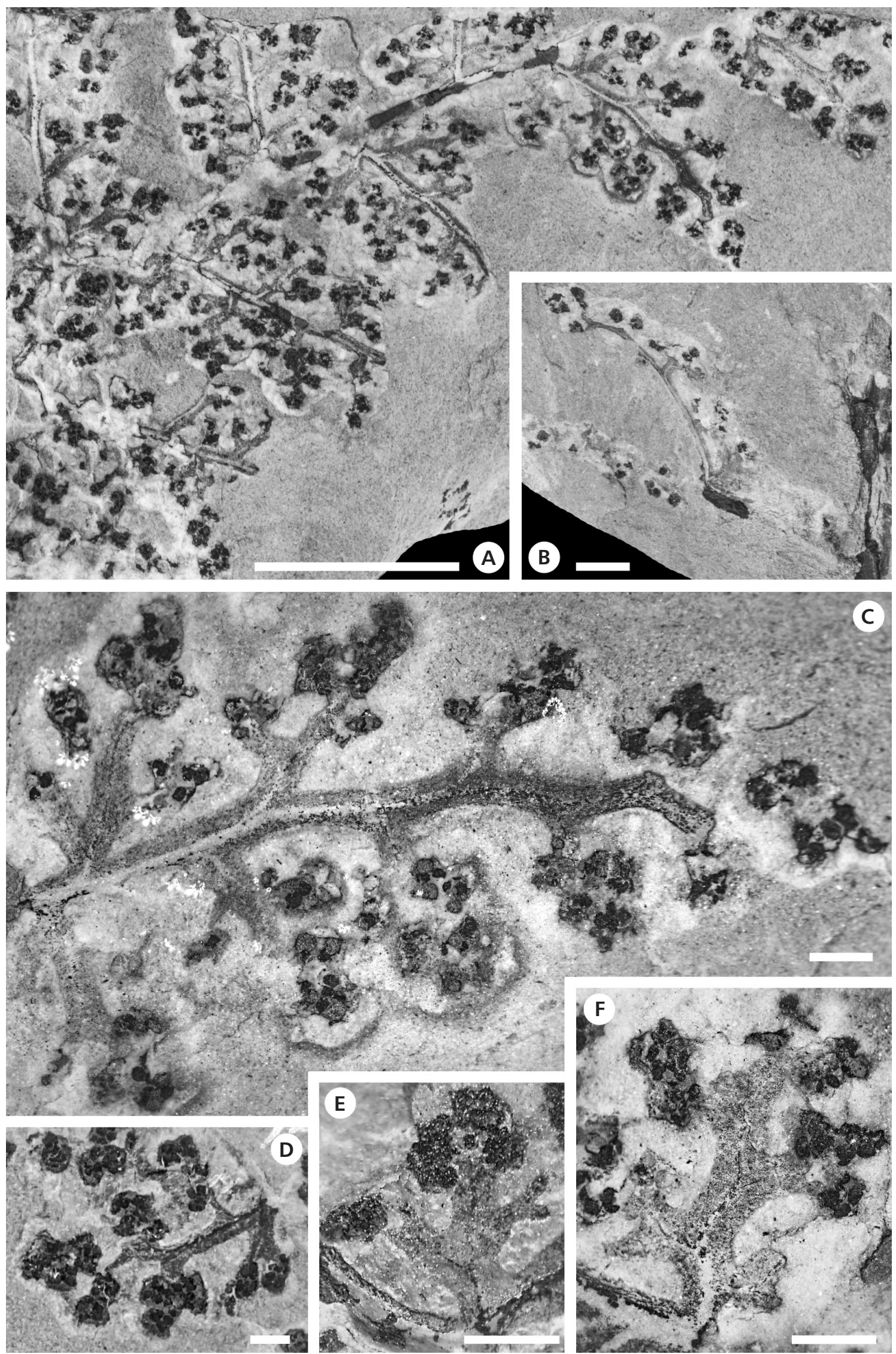

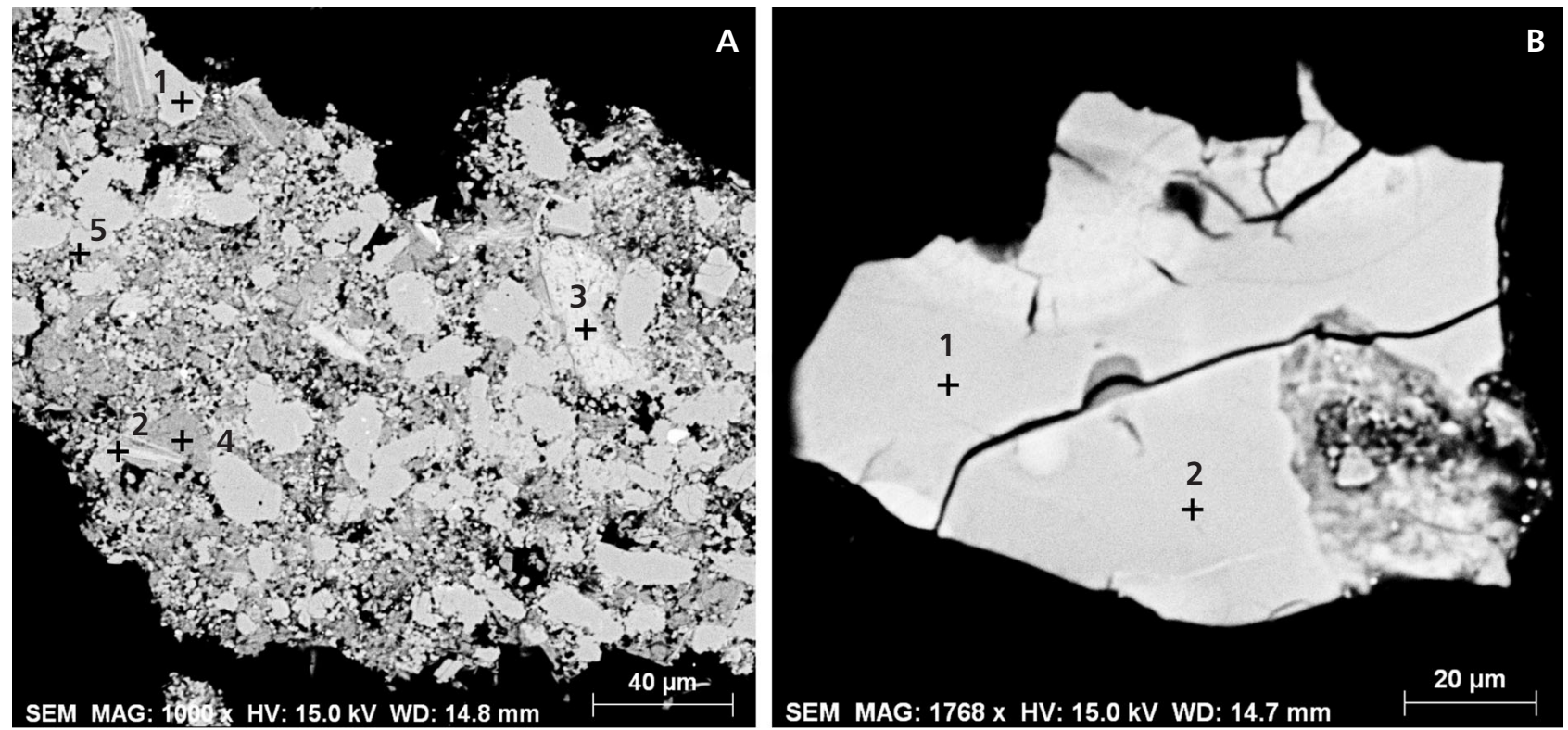

Figure 5. From lectotype. $\bullet$ A - SEM image of the whitish plant rim with location of microprobe analyses; quartz (1), muscovite (2, 3), kaolinite (4) and rutile/anatase (5) were detected. $\bullet \mathrm{B}$ - SEM image of the whitish plant rim with location of microprobe analyses which both detected same composition basic glass or obsidian.

Whetstone Horizon probably represents a complex of lacustrine sediments composed of re-deposited volcaniclastics and admixed siliciclastics deposited in the valley.

\section{Taphonomy}

Němejc's (1934) (respectively Feismantel's) specimens show more or less large parts of plant remains while our new examination of the locality section provided only several millimetres large plant detritus concentrated to thin discrete zones. Thin discrete zones with common plant detritus rarely accompanied by larger parts of plants are known from the upper re-deposited whetstone part of the Whetstone Horizon in the Radnice Basin (Opluštil et al. 2014). These authors stated that plant remains preserved in this upper whetstone part of Whetstone Horizon originally grew probably at valley margins or adjacent hill slopes and subsequently, where they were buried by volcanic ash and subsequently drifted as unconsolidated volcanic ash was washed by rains down the valley. This scenario is adopted here to explain the origin of plant detritus zones in the Whetstone Horizon exposed in near Stradonice. From petrological and mineralogical analyses follows that Whetstone Horizon contains abundant volcaniclastic components such as detrital Ti oxides, biotite, apatite and baryte cement. The presence of climbing ripples point to very fast transport and deposition in supercritical conditions, which probably resulted in rapid burial of the plant debris and contributed to their good preservation. The angular to su- bangular detrital grains support interpretation of short transport. The sedimentary facies of the deposits overlying the Whetstone Horizon (Šiftancová 2005) and our present observations (Fig. 2) of the Stradonice Whetstone Horizon and its petrology suggest that Dendraena pinnatilobata grew in close proximity to the riverside or peatland margins and preferred mineral (clastic) substrates.

Nevertheless, clear stratigraphical position of Němejc's (1934) specimens remains unknown and based on current information is impossible to clearly determine the original habitat of Dendraena pinnatilobata.

An interesting phenomenon all of the Dendraena samples from the Whetstone Horizon is whitish rim surrounding the plant (Fig. 4). The rim is typically $1-2 \mathrm{~mm}$ wide. Electron microprobe analyses of the whitish rim revealed similar composition to the whetstone (Fig. 5A). The dominant components are detrital quartz, muscovite, kaolinite and kaolinised muscovite. Minor components are detrital altered biotite and rutile/anatase. Accessory obsidian (Fig. 5B) and apatite are also present. Organic matter remains are pyritised, except for rare specimens. The pyrite has often been oxidised to Fe oxides. Baryte cement is associated with plant tissues. The Ti oxides, biotite, apatite and especially baryte are interpreted to represent minerals of volcanic origin (Pettijohn et al. 1973).

Similar whitish rim surrounding the plant was described by Barthel (2016) from volcaniclastics from Döhlen Basin (Germany). In both cases the rim is probably a kind of leaching caused by the organic matter of the plants. Some mixed-layer clay minerals (phyllosilicates) 


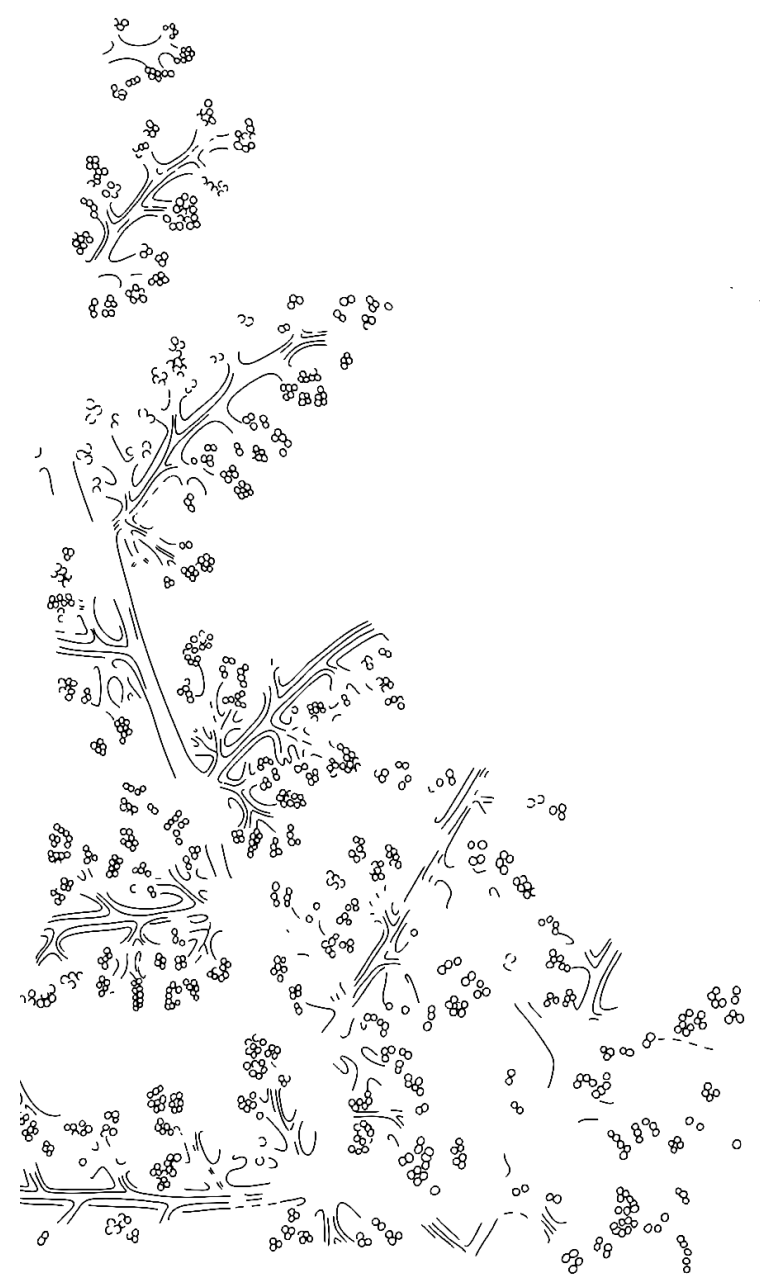

A

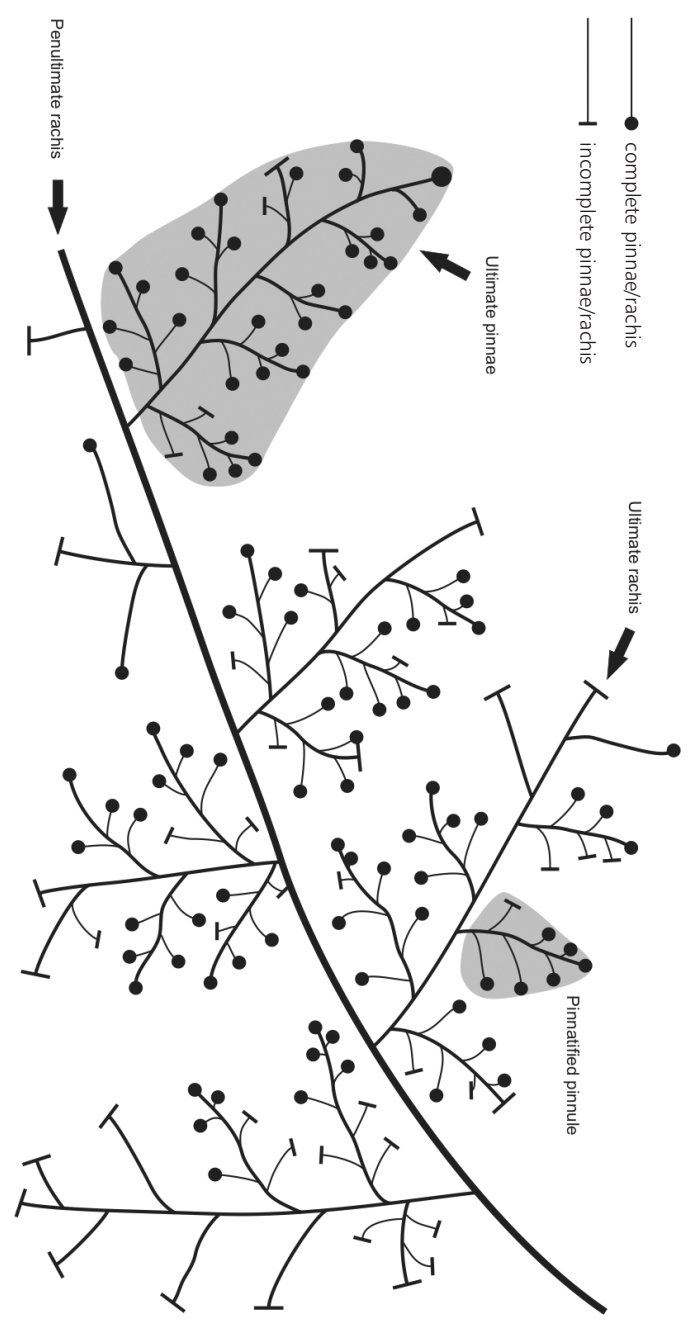

B

Figure 6. Lectotype of Dendraena pinnatilobata E 4945, scale bars $50 \mathrm{~mm}$. A - camera lucida drawing. $\bullet$ B - rachis diagram with shape of ultimate pinna and pinnatified pinnule (shaded area).

are chemically highly reactive and have a high absorbing capacity, and they react easily with organic substances. Based on Electron microprobe analyses on whetstone from Stradonice locality we identified as phyllosilicates kaolinite. It may result in genesis of whitish rim surrounding the plant.

\section{Systematic palaeobotany}

Class Filicopsida

Order Filicales

Family Anachoropteridaceae P. Bertrand, 1909

\section{Genus Dendraena Němejc, 1934}

Type species. - Dendraena pinnatilobata Němejc, 1934.
Emended diagnosis. - Pinnae triangular-ovate to ovate; penultimate rachis with C-shaped xylem strand; recurved, slightly tapered arms; pinnule pinnatifid; deeply laminar lobate, margin smooth; lateral veins two times divided; sporangia, free sessile, irregularly grouped, leptosporangiate, produced on pinnule margin; annulus of bandlateral-upper type, stomium, apical cells; spores trilete, triangular to circular, microspinate to spinate and reticulate sculpture.

\section{Dendraena pinnatilobata Němejc, 1934 emend.}

Figures 4, 8, 11, 12

Lectotype. - Specimen E 4946 (counterpart E 4945), designated here, the National Museum, Prague, Czech Republic. Remark: Němejc (1934) established the species based on several specimens that included fertile specimens from 


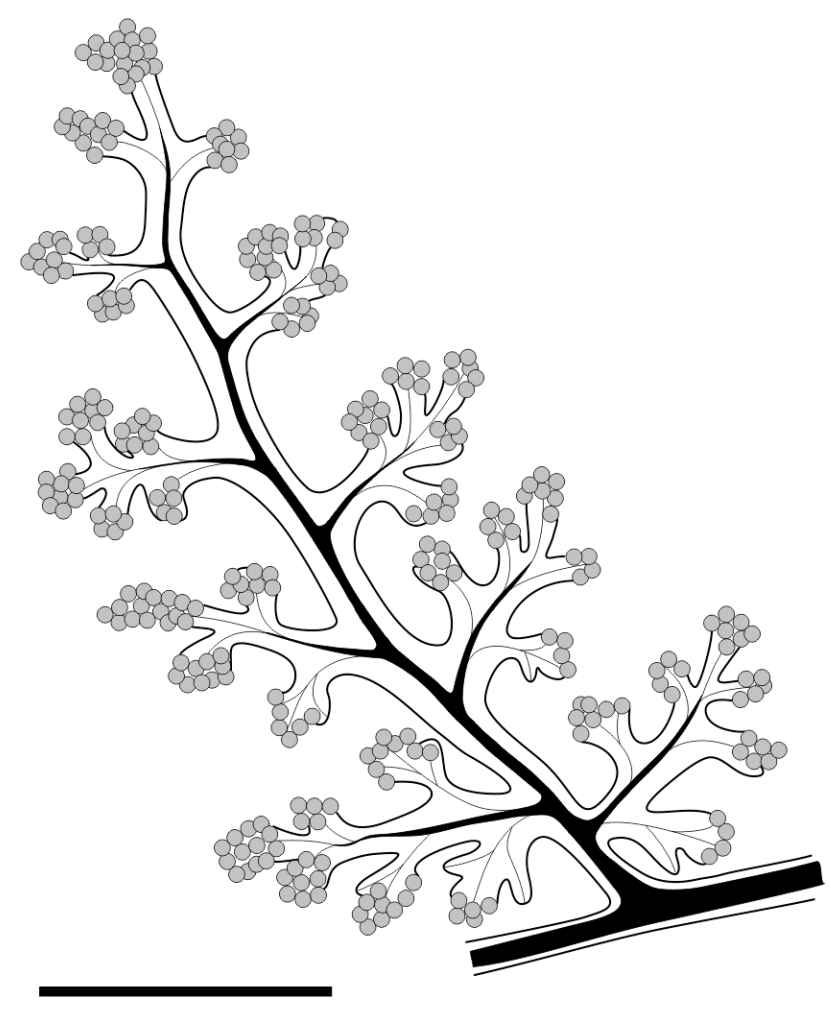

Figure 7. Reconstruction of ultimate pinnae of Dendraena pinnatilobata, scale bar $40 \mathrm{~mm}$.

Stradonice locality and also specimen E 4972 from the Štilec locality [Němejc (1934) believed that this specimen is sterile]. Nevertheless, the specimen E 4972 is fertile based on our SEM study. Its sporangia and in situ spores are different from those of $D$. pinnatilobata from the Stradonice locality. Thus, E 4972 is here removed from that taxon.

Type locality. - Stradonice, near Beroun.

Type horizon. - Whetstone Horizon, Radnice Member, Middle Moscovian (Upper Duckmantian).

Emended diagnosis. - Frond segments at least tripinnate; rachises winged; penultimate rachis xylem strand C-shaped, slightly involuted, arms recurved and slightly tapered, median part of xylem strand horizontally elongated with two lateral arms, ultimate rachis trace oval-shaped; ultimate pinnae triangular-ovate to ovate; pinnules triangular-ovate; lobes rounded; U-shaped gap between two adjacent lobes; lateral veins two times divided ending in lobe; sporangia irregularly grouped 7-18 sporangia per group, ovoid-shaped, annulate; three irregular rows of cells form a band-lateral-upper- type of annulus situated above equatorial region of sporangium, occupying a half to three-quarters of the circumferences of the sporangium; stomium of five to six rows of elongated, thick-walled cells, ongoing from apical cells to the base; apical cells at the top of sporangium and consist of three to six rows of tetragonal to polygonal thick-walled cells; thin-walled ordinary cells; trilete triangular in situ microspores, with exine microspinate to spinate and reticulate.

Description. - Frond and pinnule architecture: Němejc (1934) established the genus Dendraena and designated specimens E 4945 (part) and E 4946 (counterpart) as the lectotype. The lectotype has a well-preserved ultimate rachis, pinnules and groups of sporangia.

The frond is at least tripinnate (Fig. 6A, B). Well-preserved antepenultimate rachis (for all measurement see Tab. 1) is winged, almost straight and longitudinally striated (Fig. 4B). The shape of the pinnae of the antepenultimate pinnae is not discernible due to fragmentary preservation. Penultimate rachis is winged, longitudinally striated, almost straight, $34 \mathrm{~mm}$ long (Fig. 4A, B). The shape of the penultimate pinnae is unknown.

The ultimate rachises are longitudinally striated, slightly sinusoidal and diverge from the penultimate rachis at 55-75 degrees. The complete ultimate rachis bears maximum of 9 pinnatified pinnules (Fig. 6A, B). Ultimate pinnae are triangular-ovate to ovate (Figs 4A, B; 6, 7), $>17.5 \mathrm{~mm}$ long and $>10.5 \mathrm{~mm}$ wide.

The main veins of the pinnatified pinnules slightly sinusoidal and lies at 55-70 degrees to the ultimate rachis (Fig. 4C-E). The pinnules are triangularly ovate (Fig. 4C) and alternate along the rachis. Pinnules gradually taper toward the apex where they terminate in a small $1.5 \mathrm{~mm}$ wide apical lobe. The largest pinnules are close to the base of the ultimate pinnae. Individual lobes are 1.1-3.5 mm wide and 1.3-5.75 mm long. The lobes lie in the range of 55-70 degrees to the pinnules and are deeply laminar lobate (Fig. 4C). Each pinnule bears at minimum four lobes and has a smooth rounded margin (Fig. 4D). The number of lobes gradually decreases towards the apex of the pinnule. The space between two confluent lobes is U-shaped (Fig. 4E). The lateral veins are slightly flexuous, $0.1 \mathrm{~mm}$ wide and bifurcated three times.

Reproductive organs: Poorly preserved reproductive organs are represented by annulate marginal sporangia (Figs 8A-G, 9) situated at the end of the pinnule lobes (Fig. 8F). It is impossible to state whether the sporangia arise from the pinnule lamina or from lateral veins. Whole pinnules are covered by a number of irregularly grouped sporangia (7-18 sporangia per group; Fig. 8A). Sporangia are free, sessile on the pinnule, ovoid-shaped, annulate, with their longer axis 190-494 $\mu \mathrm{m}$ and their shorter axis 190-310 $\mu \mathrm{m}$ (Fig. 10, Tab. 1). The sporangial wall consists of one sporangial cell layer. It is possible to discern four types of sporangial cells: cells of the annulus, stomium, apical cells and ordinary cells. 
Table 1. Comparison of some morphological characters of Dendraena pinnatilobata. The size of pinnules represent the large pinnules. The most common size of sporangia can be also seen on Fig. 10; abbreviations: Ul-P - ultimate pinnae, Ul-R - ultimate rachis, Pu-P - penultimate pinnae, Pu-R - penultimate rachis, Ant-R - antepenultimate rachis, $\mathrm{B}$ - near the base; the numbers of sporangia are in $\mu \mathrm{m}$, the numbers in brackets show the size with winged lamina.

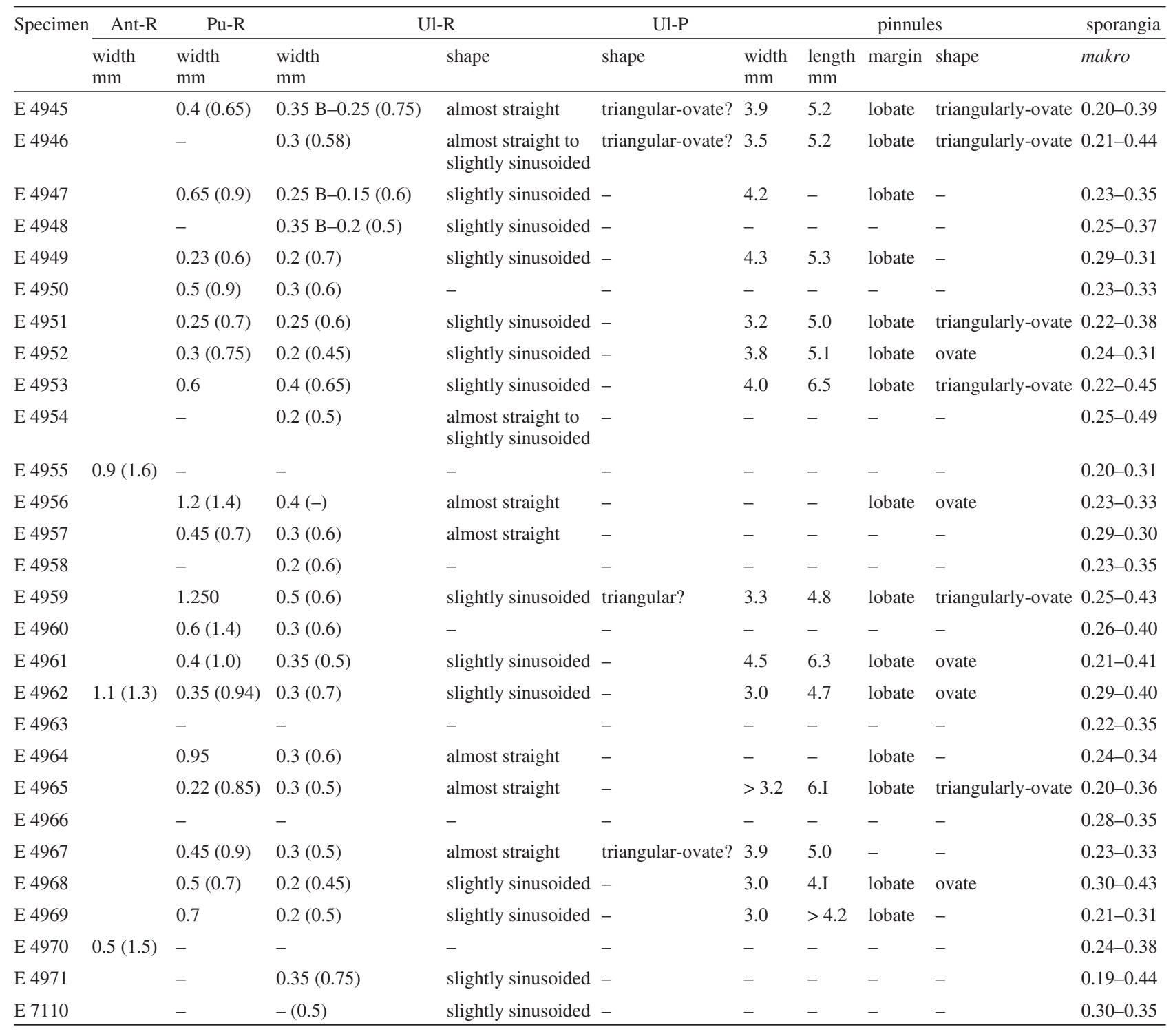

1) Cells of the annulus are located above the equatorial part of the sporangium (Figs 8A, C, G “AC", 9) and occupy half to three-quarters of the sporangium circumference (Fig. 8B, D). The annulus consists of 3 irregular rows of thick-walled elongated tetragonal/polygonal cells (Fig. 8B, $\mathrm{D}, \mathrm{G})$, which are 50-63 $\mu \mathrm{m}$ long and 30-45 $\mu \mathrm{m}$ wide. Anticlinal walls of cells are straight. The annulus can be classified as a band-lateral-upper annulus. This lateral type of annulus is located over the equatorial area of the sporangium with a band shape and occupies a half of the sporangia.

2) The stomium cells, (Fig. 8C, E, G "SC") consist of 5-6 rows of thick-walled elongated cells, 35-50 $\mu \mathrm{m}$ long and $7-15 \mu \mathrm{m}$ wide. The anticlinal walls are straight to undulate. These cells probably penetrate from the apical cells of the sporangium to the base of the sporangium. The stomium is on the opposite side of the annulus.

3) The apical sporangial cells (Figs 8D, E, G, 9) are tetragonal (Fig. 8D, G “APC"), sometimes polygonal, which might be influenced by the preservation. These cells consist of 5-6 rows of thick-walled cells (Fig. 8D, E, G "APC"). The apical cells are 13-23 $\mu \mathrm{m}$ long and 9-17 $\mu \mathrm{m}$ wide.

4) The ordinary cells occupy the remaining sporangia, are thin-walled and not always preserved.

In situ spores: Trilete microspores with triangular, subtriangular, circular to subcircular amb (Fig. 11A-F). Size range is 21 (27.4) $48 \mu \mathrm{m}$ (Fig. 11D-F). Sides are usually convex, but may be occasionally straight or rarely con- 
cave. Two types of microspores were observed (Fig. 11E). First smaller microspores are of 21 (23) $25 \mu \mathrm{m}$ in diameter (Fig. 11B-C). Amb is triangular to subtriangular with concave sides. Rays of trilete marks reach three-quarters of the radius. Exine is $1-1.5 \mu \mathrm{m}$ thick and covered by microspinae and spinae. Spinae are connected at their bases by an irregular reticulum with circular lumina about $1 \mu \mathrm{m}$ in diameter. Larger microspores are of 21 (31.8) $48 \mu \mathrm{m}$ in diameter (Fig. 11D-F). Amb is circular to subcircular and subtriangular. Sides are convex, rarely straight or slightly concave. Rays of the trilete mark reach three-quarters to almost the whole radius. Exine is $1-1.3 \mu \mathrm{m}$ thick. The sculpture is granulate to spinate. Sculpture elements are connected at their bases and create a reticulum with a lamina up to $1 \mu \mathrm{m}$ in diameter.

The only in situ record of Microreticulatisporites [M. nobilis (Wicher) Knox] is known from Radiitheca dobranyana Brousmiche et al. (1985) from the Pennsylvanian of Czech Republic. These in situ microspores are comparable to the same dispersed genus, but Microreticulatisporties nobilis differs from M. harrisonii, microspores isolated from Dendraena pinnatilobata by the type of sculpture (M. nobilis has foveolate and M. harrisonii has granulate and spinate sculpture).

Dispersed Microreticulatisporites: A dispersed miospore genus Microreticulatisporites was proposed by Knox (1950) and emended by Potonié \& Kremp (1954). The most characteristic morphological feature is a negative reticulum, i.e., small perforations of the exine. Although the type species [M. lacunosus (Ibrahim) Knox] is from the Pennsylvanian, today the genus consists of $c a$ 150 dispersed miospore species from the Carboniferous to the Tertiary (Eocene). M. harrisonii is not a typical representative of the genus because, although it possesses typical perforations of the exine, it also has a developed spinae.

Only M. nobilis (Wicher) Knox has some stratigraphical significance in the Carboniferous of the Czech Republic, because its records are typical mainly for the Stephanian B strata (Pešek et al. 2001).

Anatomical structures: Two specimens (E 4955 and E 4970 on Fig. 12A, B) have three-dimensionally preserved penultimate rachises showing an internal anatomy. Both rachises are poorly preserved, but cells and the shape of the xylem strands are discernable. The rachises are $1.3 \times$ $0.8 \mathrm{~mm}$ wide (Fig. 9). Portions of the xylem strands are not preserved or have been destroyed (Fig. 13; black areas with question marks). The median part of the xylem strand is horizontally elongated with two lateral arms, bent towards the median plane (Figs 13; 12C, D). The xylem strand is C-shaped, slightly involute, with recurved and slightly tapered arms, $0.8 \times 0.5 \mathrm{~mm}$ across. The radial/tangential width ratio is $c a 0.6$. The xylem strands consists of several thick cells, around $200 \mu \mathrm{m}$ wide at the broadest part of the arms. The outer border of arms' tips is difficult to discern but what is discernible suggests that they are rounded. The large metaxylem cells are ca $100 \mu \mathrm{m}$ in diameter. The protoxylem strands are not visible, but in some parts it is possible to observe small cells ca $30 \mu \mathrm{m}$ in diameter, which may represent adaxially protruding crescentic cups (Fig. 12C, D arrows). The departing ultimate rachis trace is initially oval, 200-250 $\mu \mathrm{m}$ in diameter (Figs 13 "URT"; $12 \mathrm{C}-\mathrm{D}$ "URT"). The cortex is not preserved.

Anatomical structures are poorly preserved, cannot be described in detail, compared with other fern taxa and, therefore, can be classified only as Anachoropteris sp.

Remarks. - Smaller, less abundant microspores are interpreted as immature. The larger, more common specimens can be compared with dispersed miospores indentified as Microreticulatisporites harrisonii Peppers.

\section{Discussion}

The present paper described specimens of Dendraena pinnatilobata with well-preserved reproductive organs including in situ spores and a rachial anatomy. The pinnae of D. pinnatilobata with reproductive organs are organically connected on the rachis of the Anachoropteris type (Figs 4A, B; 5).

\section{Comparison of reproductive organs with similar taxa}

A similar connection of Anachoropteris sp. rachis with

Figure 8. Fertile specimens of Dendraena pinnatilobata. All specimens stored in National Museum in Prague, Czech Republic, Němejc's collection. All specimens are from locality Stradonice, near Beroun, Radnice coal group, Moscovian. • A - grouped sporangia with lateral annulus consisting of thick-walled cells (AC) of E 4946; SEM low vacuum, scale bar $150 \mu \mathrm{m}$. • B - sporangia with lateral annulus consisting of thick-walled cells (AC), SEM low vacuum, E 4946, scale bar $100 \mu \mathrm{m}$. $\bullet \mathrm{C}$ - lateral view of sporangia with lateral annulus consisting of thick-walled cells (AC), elongated thick-walled cells of stomium (SC) of E 4946, SEM low vacuum, scale bar $100 \mu \mathrm{m}$. $\bullet$ D - sporangia with lateral annulus consisting of thick-walled cells (AC) and apical thick-walled cells (APC) of E 7110, SEM, scale bar $50 \mu \mathrm{m}$. $\bullet$ E - sporangia with lateral annulus consisting of thick-walled cells (AC), elongated thick-walled cells of stomium (SC), apical thick-walled cells (APC) of E 7110 and in situ spores Microreticulatisporites harrisonii-type; SEM, scale bar $100 \mu \mathrm{m} . \bullet \mathrm{G}$ - lateral view of sporangia with lateral annulus consisting of thick-walled cells (AC), elongated thick-walled cells of stomium (SC) and apical thick-walled cells (APC) of E 4946, SEM low vacuum, scale bar $50 \mu \mathrm{m}$. 

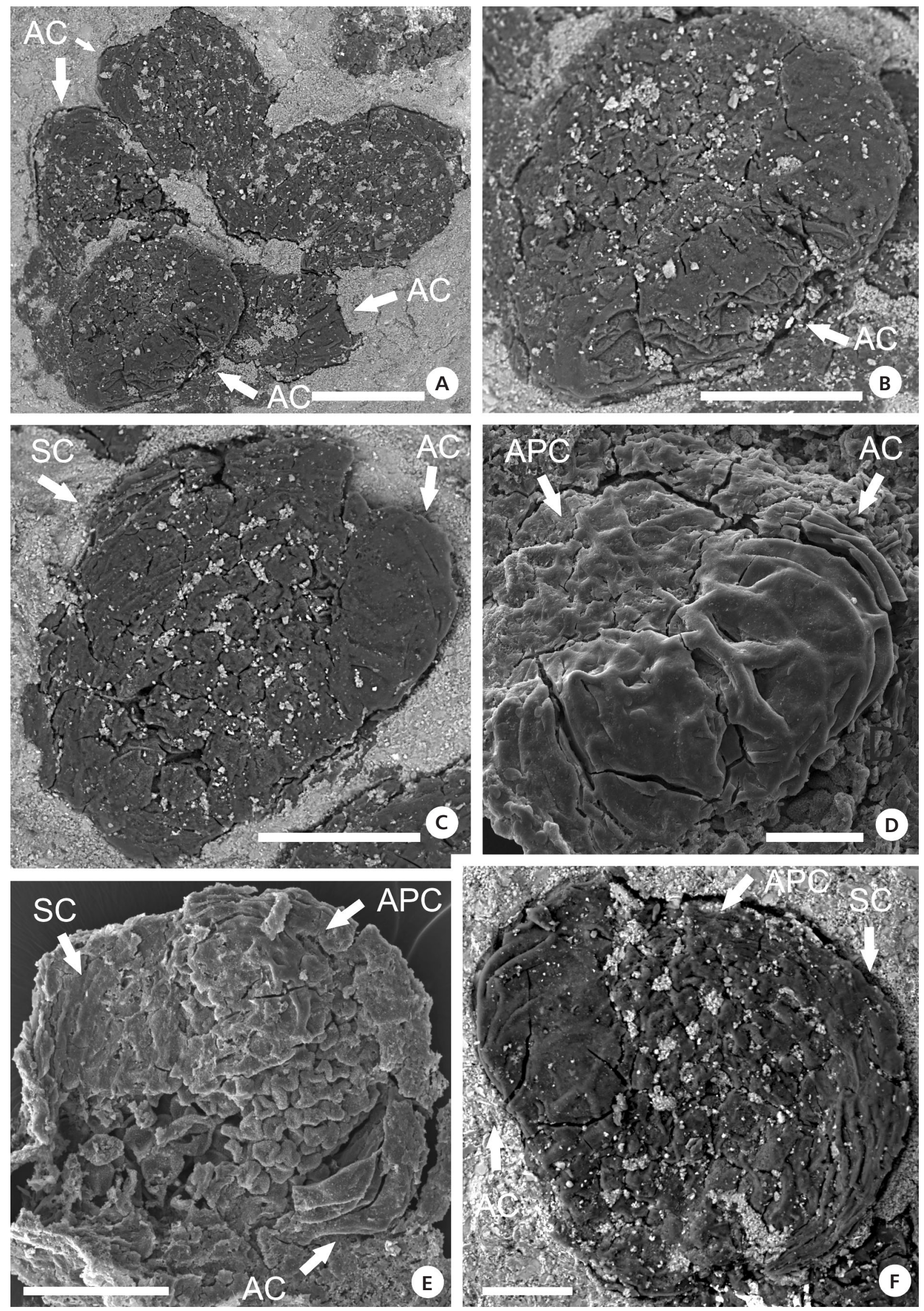


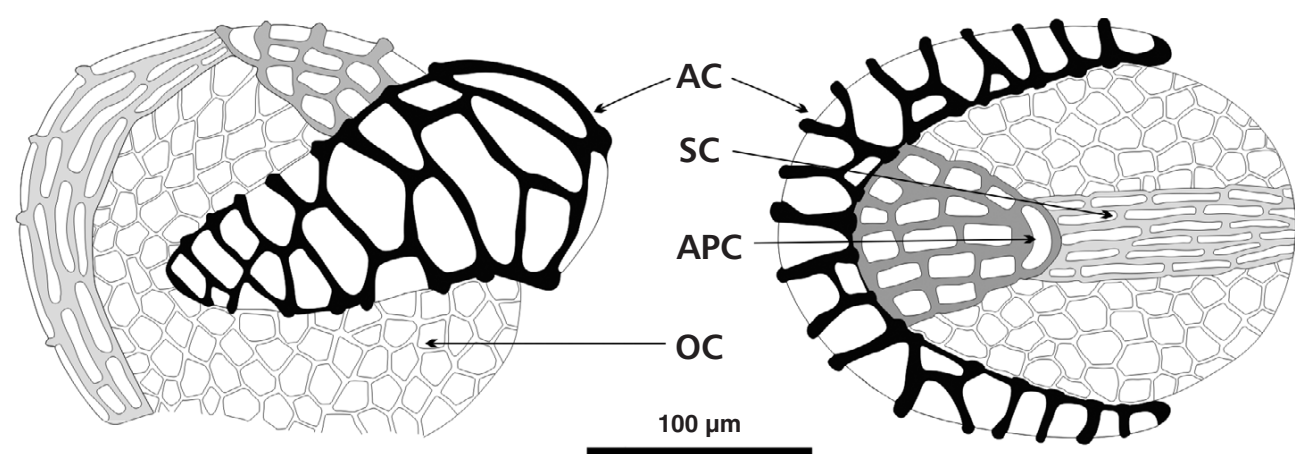

25.00

20.00

15.00

10.00

5.00

0.00

$\%$
Figure 9. Reconstruction of sporangium of $D$. pinnatilobata, $\mathrm{AC}$ - cells of band-lateral-upper annulus, $\mathrm{SC}$ - cells of stomium, APC - apical cell/cells, OC - ordinary cells. - A - side view. - B - view from above.

Figure 10. Percentage of individual lengths sporangia in $\mu \mathrm{m}$.

a fertile specimen (Figs 4, 10) was described by Galtier \& Phillips (2014, pl. 11, figs 1-13) from the Middle Pennsylvanian equivalent of the Murphysboro Coal (Cayuga, Indiana, USA). It is still the only known fertile specimen attached to an Anachoropteris rachis. The fertile pinnae of Anachoropteris have multiply branched $2 \mathrm{~mm}$ long soral receptacles attached in paired parallel lines to the adaxial face on the pinnule (Galtier \& Phillips 2014, pl. 11, figs 7-9). The spherical $(0.4-0.5 \mathrm{~mm})$ sporangia, each has an oblique lateral annulus and are attached in two rows of thick-walled cells at the end of the short stalked receptacle branch. The position of the annulus is low on one face near the stalk (Galtier \& Phillips, 2014, pl. 11, figs 7, 11-13). The stomium consists of narrow elongated cells, to near the basis (Galtier \& Phillips, 2014, pl. 11, fig. 10). This fertile frond has unidentified immature in situ spores $30 \mu \mathrm{m}$ in diameter. In contrast, Dendraena has no soral receptaculum, but has sessile free sporangia, irregularly grouped, 0.190-0.494 $\mathrm{mm}$ in diameter, ovoid-shaped with band-lateral-upper annulus, which is formed from three rows of thick-walled cells (Tab. 2). Several fossil-genera of true ferns with lateral annuli are known, but Microreticulatisporites is the only taxon known from in situ spores. These in situ spores are attached to Radiitheca dobranyana (Brousmiche et al., 1985) from the Pilsen Basin, Dobré Štestí locality, Moscovian (Asturian). Radiitheca has pecopterid type of pinnules. The sporangia of Radiitheca are grouped into sori with $15-35$ sporangia $(0.5-0.8 \mathrm{~mm}$ long axis) with apical annuli while sporangia of Dendraena pinnatilobata have a band-lateral-upper annulus, a sporangia (0.190-0.494 mm longer axis) attached to sphenopterid type pinnules. Thus Radiitheca dobranyana represents a plant with a different affinity than Dendraena pinnatilobata.

Dendraena pinnatilobata exhibits features similar to some species of several genera; Sturia Němejc (S. amonea Němejc), Tenchovia (Pšenička \& Bek), Boweria (Kidston) and Kidstoniopteris (Frojdová et al.), Oligocarpia (Goeppert), Chansitheca (Regé), Sturiella (Weiss), Todeopsis (Renault), Discopteris (Stur), Kidstonia

Figure 11. In situ microspores of the Microreticulatisporites harrisonii-type isolated from Dendraena pinnatilobata, Stradonice locality, Moscovian stratigraphy. $\bullet$ A - E 4962, proximal surface. Note the length of rays of the trilete mark and the sculpture. Scale bar is $10 \mu \mathrm{m}$. $\bullet$ B - E 7110 , mass of microspores. Note concave sides. Scale bar is $25 \mu \mathrm{m}$. $\bullet$ C - E 4962, slightly damaged proximal surface of microspore with concave sides. Scale bar is $10 \mu \mathrm{m}$. - D - E 7110, mass of microspores with straight or slightly convex sides. Scale bar is $25 \mu \mathrm{m}$. • E - E 7110 , mass of microspores. Relatively immature microspores with concave sides (right) and matured microspores (left) with convex sides. Note difference between immature and matured specimens. Scale bar is $25 \mu \mathrm{m}$. $\bullet \mathrm{F}-\mathrm{E} 4946$, lectotype, distal surfaces. Scale bar is $10 \mu \mathrm{m}$. 

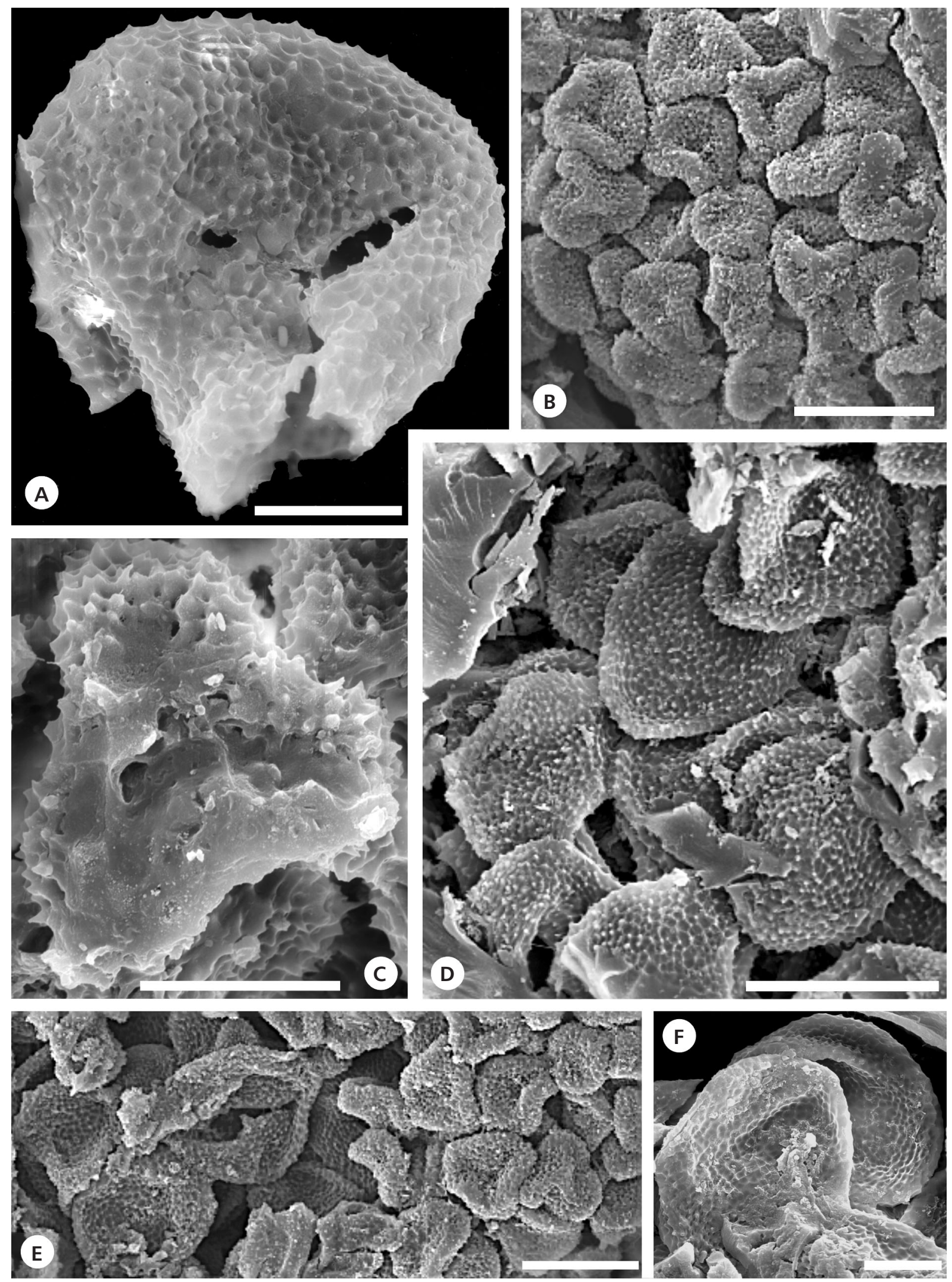

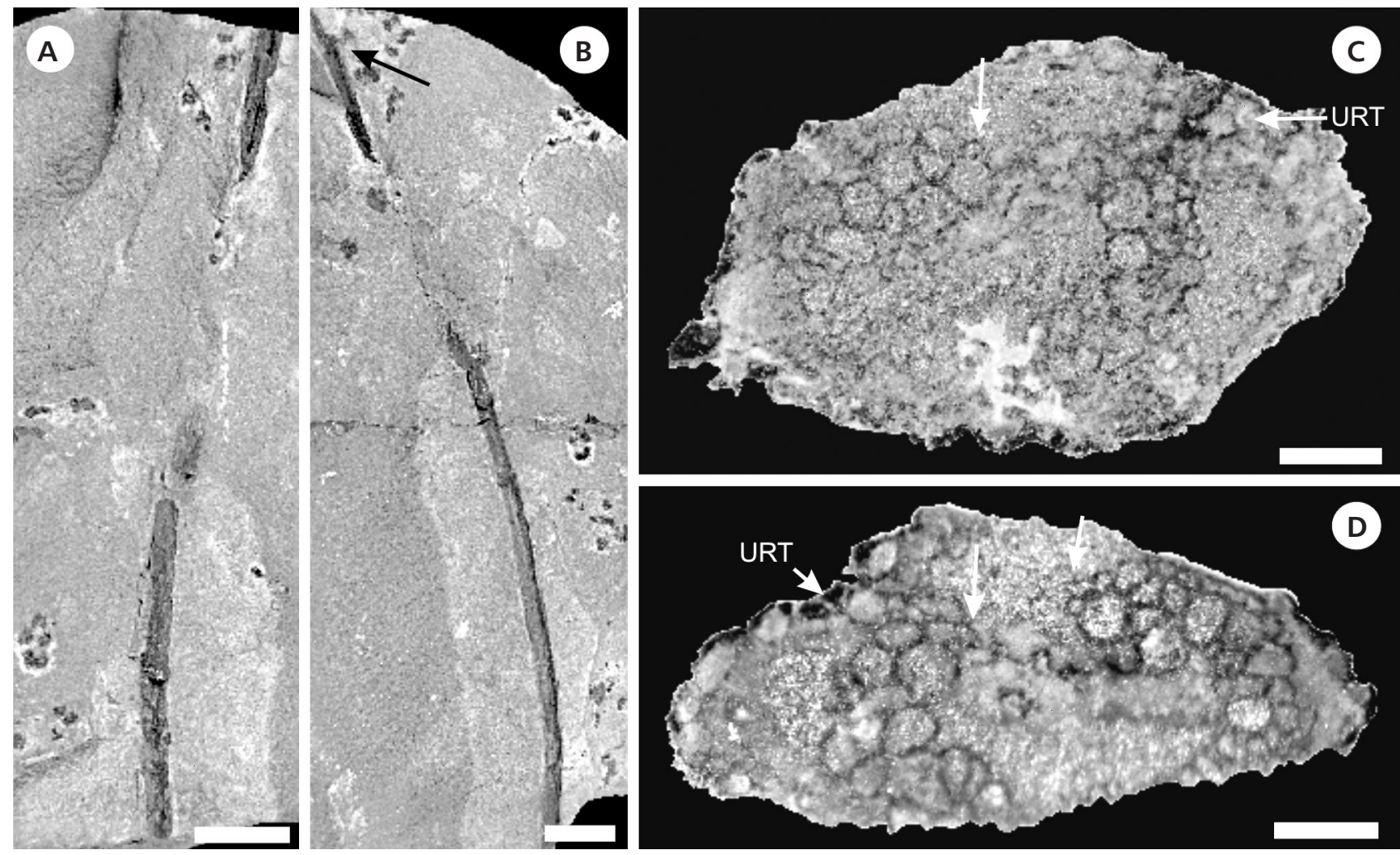

Figure 12. A - D. pinnatilobata $\mathrm{E} 4955$, three-dimensionally preserved penultimate rachis. $\bullet \mathrm{B}-$ D. pinnatilobata $\mathrm{E} 4970$, three-dimensionally preserved penultimate rachis. $\bullet \mathrm{C}$ - cross section of the penultimate rachis of $D$. pinnatilobata $\mathrm{E} 4955$, "URT" - ultimate rachis trace. $\bullet \mathrm{D}-$ cross section of the penultimate rachis of $D$. pinnatilobata $\mathrm{E} 4970$, "URT" - ultimate rachis trace.

(Zeiller), Hymenophyllites (Goeppert) and Pteridotheca (Scott) (see Tab. 2).

Dendraena pinnatilobata has features quite similar to Kidstoniopteris minor (Kidston) Frojdová et al. (2017); the type specimen consists of reproductive organs and an extremely reduced pinnule lamina. This species has irregularly grouped sporangia with semi-lateral annulus occurring at the end of the lateral veins. They both have irregularly grouped ovoid-shaped sporangia and the annulus consists of 3 rows of thick-walled cells. The size of the sporangia of $K$. minor and $D$. pinnatilobata is comparable (Tab. 2). Other common features between them are the triangular ovate shape of the pinnae and the deeply lobate pinnule. Major differences between these two taxa are in the number of sporangia per group (Tab. 2) and K. minor (Frojdová et al.) has stalked sporangia while in $D$. pinnatilobata here has sessile sporangia. K. minor has a more complex rachial system than $D$. pinnatilobata; the shape of the ultimate rachises in $K$. minor is sinusoidal to very sinusoidal in comparison to $D$. pinnatilobata. It is not now known if the differences in the diameter of the pinnules in these two taxa are diagnostic or the reflection of ecologic variations resulting from having grown in different biotopes seen in recent forests (Lehnert \& Weigand 2013). K. minor has a semi-equatorial annulus in contrast to D. pinnatilobata that has a band-lateral-upper annulus and the number of rows of cells of the stomium is different too. Finally, K. minor produced GranulatisporitesApiculatisporites-Leiotriletes-types of spores while D. pinnatilobata produced Microreticulatisporites-type of in situ spores. Boweria is fern with a sphenopterid or pinnatified pinnules with lobate margins and free leptosporangiate sporangia. Sporangia of Boweria are short stalked and placed at the end of the veins at the margin and are composed of four types of cells with a lateral shield-like annulus. The main difference between Boweria and Dendraena is in diameters of the sporangia (Tab. 2). Boweria also does not have grouped sporangia with a short pedicel and produced Granulatisporites-Leiotriletes-types of in situ spores, i.e., different from those isolated from Dendraena pinnatilobata. Finally, Boweria is typified by basal acroscopic pinnules of the ultimate pinna larger than the basal basiscopic pinnules, it is not observed in pinnules of Dendraena.

Sturia, according to Němejc (1934) and Frojdová (2013) has annulate sporangia, which are sessile, free, oval in shape and $0.4-0.5 \mathrm{~mm}$ long. The annulus of Sturia is very distinct, placed nearly at the top of the sporangium in a vertical direction, biseriate, and occupies about two-thirds of the sporangium's circumference of in its 
equatorial part. Cells of the annulus are twice as large as the ordinary cells. The sporangia are placed on the pinnules close to their margin. One of the dissimilarities is in the ungrouped sporangia, which are also larger in Sturia than those of $D$. pinnatilobata, which are irregularly grouped. The type of pinnule is also different, Sturia has a more deeply lobate pinnule, but $D$. pinnatilobata has a more laminar and lobate pinnule. Němejc (1934) stated that the main difference is the occurrence of aphlebia in Sturia. Sturia produced a Punctatosporites-type of in situ spores, i.e., different from those described for Dendraena pinnatilobata (Tab. 2).

Kidstonia is another fern genus with annulate sporangia. The sporangia of Kidstonia (resp. K. heracleensis) are ovoid, 0.3-0.4 mm long and consist of several types of cell (Zeiller 1897). Larger and thick-walled cells represent annulus, which could be classified as a semi-apical type of annulus Zeiller (1897, p. 213, figs 5, 6). Zeiller (1897) mentioned that the annulus occupies three-quarters of the upper hemisphere of the sporangium. The ordinary cells of the sporangia consist of elongate, narrow cells. A band of thin-walled cells represents the stomium. In situ spores from Kidstonia are unknown (Frojdová et al. 2017). The main difference between both taxa (D. pinnatilobata and Kidstonia) is in the position of the sporangia: Kidstonia has sporangia on the lower side of the pinnules near the pinnule basis, while the sporangia of $D$. pinnatilobata are situated on the pinnule margin (Tab. 2).

Discopteris Stur, 1883 is characterised by sporangia in sori with an apical annulus. Pfefferkorn (1978) and later Brousmiche (1983) stated that sporangia of Discopteris are formed by radial rows of thick-walled, polygonal cells, which occupy most of the sporangium wall. Therefore some authors (e.g. Zeiller 1899; Pšenička 2005) emphasized that the sporangia of Discopteris are annulate with a semi-apical lateral annulus (Tab. 2). The sporangia of Discopteris are grouped in a rounded sorus in a large number, placed in the central or marginal part of the pinnule, whereas the sporangia of $D$. pinnatilobata are strictly situated in the marginal part of the pinnule.

Another genus Tenchovia was defined (Pšenička \& Bek 2004) as a true fern with "sphenopterid" pinnules and annulate sporangia. The sporangia of Tenchovia are grouped into sori. This feature can be comparable with the irregularly grouped sporangia of $D$. pinnatilobata. Nevertheless, the sporangia of Tenchovia have a bean-shaped lateral-lower annulus, quite different from annulus of $D$. pinnatilobata (Tab. 2). Moreover, the in situ spores are different from those macerated from D. pinnatilobata (Tab. 2).

Němejc (1934) emphasized the importance of lateral sporangia of Pteridotheca, Sturiella and Todeopsis (Tab. 2) isolated from permineralised nodules. The genus Pteridotheca Scott (resp. P. Williamsoni) is known as isolated sporangia from calcareous nodules (Scott 1909). The
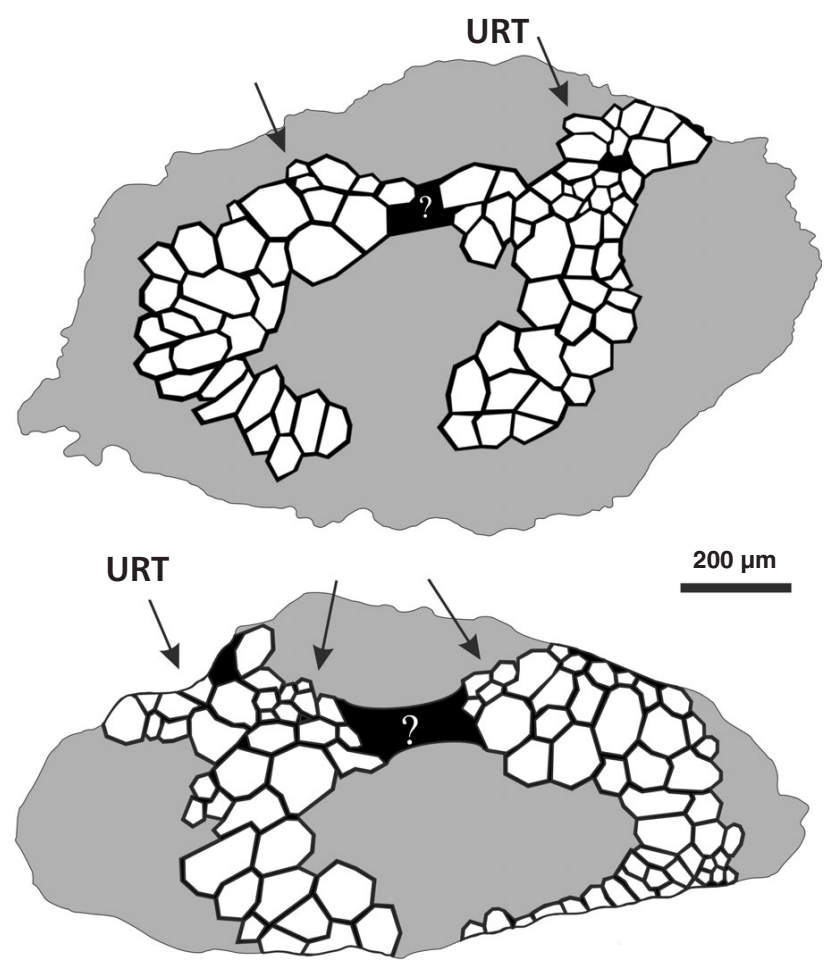

Figure 13. Camera lucida drawing of transversal section from penultimate pinnae of D. pinnatilobata E 4955 and E 4970. "URT" - ultimate rachis trace.

pinnules of Pteridotheca are apparently of the sphenopterid type; its nearly spherical sporangia are sessile with a multicellular base and a row of thick-walled cells forming the annulus and are located on the marginal pinnule. Two rows of cells form the annulus. The in situ spores are unknown as is the shape of the pinnule and pinnae.

The genus Sturiella Weiss belongs to the group of Osmundales (Scott 1920) or Psaroniaceae (Němejc 1963). Sturiella is known as having isolated sporangia and pinnules. Sporangia form pyriform sori with apical-oblique annulus. Five sporangia grow together at the base of a cap-like annulus expanding to the vertical direction of the two opposite sides (Němejc 1963, p. 403).

The genus Todeopsis Renault is known only from a transverse section of sporangia lacking an annulus (Renault 1896). The transverse section shows a row of thick-walled cells consisting of an annulus as depicted by Renault (1896). Renault (1896) and Němejc (1963) described pyriform non-annulate sporangia with a short pedicel, $0.33 \mathrm{~mm}$ in diameter and Renault (1896) mentioned five larger cells that can be interpreted as an annulus. Three smaller cells are perpendicular to the axis of the sporangia; it means they may resemble a stomium. Neither of these genera is similar to the genus Dendraena.

Another genus with annulate sporangia is Hymenophyllites Goeppert. It has sporangia grouped into sori situated at the end of the lateral veins or at the end of the lobes 
(Tab.2). Sporangia are free, ovoid, $0.5-0.7 \mathrm{~mm}$ in diameter with an annulus consisting of two rows of thick-walled cells extending from the equatorial part to almost the top of the sporangia. Hymenophyllites has an indusium (Zeiller 1883) and an oblique annulus (Brousmiche 1986), i.e., both these features do not correspond to the diagnosis of Dendraena. In situ spores are unknown.

The sporangia of the genus Chansitheca (resp. Ch. palaeosilvana) are rounded, grouped into sori (He et al. 2016) and with an oblique annulus (Regé 1920, He et al. 2016) that is almost in the central part of the sporangia and consists of two rows of thick-walled cells that are different from Dendraena (Tab. 2).

The sporangia of the genus Oligocarpia Goeppert are grouped into sori, and placed at the end of the lateral veins. The annulus is directed out of the sorus (Tab. 2). In situ spores are of the Granulatisporites-type (Remy \& Remy 1957, Brousmiche 1983), i.e., different from those described for Dendraena pinnatilobata. The shape of the pinnule is different too, because Oligocarpia has no separate simple pinnule on the individual lobes.

Finally, the annulate sporangia of Dendraena may be intermediate among taxa with a biseriate and uniseriate annulus, i.e., filicalean ferns (Galtier \& Phillips 1996, 2014).

\section{Comparison of anatomy with similar taxa}

The rachises of Dendraena pinnatilobata has an abaxially curved C-shape traces as do Anachoropterid ferns (Galtier \& Phillips 2014) with typical member Anachoropteris Corda. Corda (1845) distinguished Anachoropteris Corda; Whetstone Horizon of the Radnice Member (Upper Duckmantian); from other taxa on its rachial anatomy with its characteristic involute vascular strand. The holotype (Corda 1845, pl. 56, figs 1-2) represents a $2.7 \mathrm{~mm}$ broad primary rachis (penultimate rachis) and shows strongly involute xylem anatomy, a dense cortex and hairs. Rachises of $D$. pinnatilobata are only $1.3 \mathrm{~mm}$ wide comparable to the smaller rachises (1.5 $\mathrm{mm}$ in diameter) Anachoropteris rotundata Corda (Corda 1845, pl. 54, figs 7-9). A. rotundata has a slightly involuted C-shaped xylem strand as do the specimens described herein (Fig. 12C, D).

Later Galtier \& Phillips (2014) revised the Anachoropterid ferns and established four groups based on morphological/evolutionary trends: "gillotii-radnicensis", "robusta", "williamsonii" and "pulchra-involuta" groups.

Galtier \& Phillips (2014, p. 34) synonomized A. rotundata with $A$. pulchra as the former represents secondary (penultimate) rachises of the later. The "gillotiiradnicensis" Anachoropteris group is characterised by a short, thick foliar xylem with very short arms (Galtier \& Phillips 2014) where as Dendraena has thick foliar xylem, but longer arms. These longer arms also present in the Anachoropteris "robusta group". Anachoropteris species from the "robusta group" are, however, similar to the "gillotii-radnicensis group" but the "robusta group" is different by having xylem strands with arms of short lengths (Galtier \& Phillips 2014). Galtier \& Phillips (2014, p. 53, pl. 11) also described fertile pinnae (attached sporangia to petiole) with an anachoropterid anatomy from the Middle Pennsylvanian of the Illinois Basin. Galtier \& Phillips (2014) stated that these specimens yielded sori superficially borne on the adaxial surface of the pinnules with an upright sorus consisting of a multi-branched vascularised stalk, bearing sporangia terminally. This is the only known example, in the anachoropterids of biological connection of the rachial anatomy and reproductive organs (Galtier \& Phillips 2014). DiMichele \& Phillips (2002) and Galtier \& Phillips (2014) emphasized, that many species of Anachoropteris were much like modern "climbing" ferns and it is possible that D. pinnatilobata was a climbeder or scrambeler as well, though no grasping shoots are preserved. It is proven that Dendraena pinnatilobata was born on rachises of the Anachoropteris robusta-type, based on the connection of rachises with anatomical structure and pinnules of D. pinnatilobata (Fig. 12). The pinnules of Anachoropteris robusta were not known by Galtier \& Phillips (2014, p. 44). The anatomical structures of Dendraena pinnatilobata are similar to the structures observed in the Anachoropteris robusta group.

\section{Plant assemlage of Whestone Horizon from Stradonice locality}

According to Němejc $(1930,1953 b)$ the plant assemblage of the Stradonice Whetstone consists of lycopsids Lepidodendron aculeatum Sternberg and Sigillaria sp., sphenopsids Asterophyllites equisetiformis (Schlotheim) Brongniart associated with cones Calamostachys intermedia Němejc, Annularia stellata (Schlotheim ex Sternberg) ferns Sphenopteris (Zeilleria?) haidingeri Ettingshausen, Zeilleria hymenophylloides Kidston, Oligocarpia lindsaeoides (Ettingshausen) Stur, Senftenbergia plumosa (Artis) Stur, Hymenophyllites bronni Gutbier, Mariopteris nervosa (Brongniart) Zeiller, Lobatopteris miltonii (Artis) Wagner, noeggerathioids Rhacopteris asplenites (Gutbier) Němejc and Palaeopteridium reusii Ettingshausen, seed plants Odontopteris britannica Gutbier, Neuropteris coriacea Ettinshausen, Linopteris neuropteroides (Gutbier in Geinitz) Potonié, Mixoneura ovata (Hofmann) Zalessky, Lonchopteris rugosa Brongniart or Triphyllopteris rhomboidea (Ettingshausen) Schimper. Some taxa cannot be clearly classified to ferns or seed plants as Sphenopteris flexuosissima Stur, S. intermedia Neuburg or S. artemisiaefolioides Crépin (Němejc 1930). Many taxa of Whestone 
Table 2. Comparison of Dendraena with other Carboniferous fossil-genera of ferns which are similar type of annulus and with type of in situ spores.

\begin{tabular}{|c|c|c|c|c|c|c|c|}
\hline genus & published in & position & $\begin{array}{l}\text { organisation (number of } \\
\text { sporangia per group) }\end{array}$ & base & type of annulus & type of in situ spores & $(\mu \mathrm{m})$ \\
\hline Dendraena & $\begin{array}{l}\text { Němejc (1934), } \\
\text { present paper }\end{array}$ & $\begin{array}{l}\text { at the end of pinnules } \\
\text { lobes }\end{array}$ & irregular grouped (7-18) & sessile & $\begin{array}{l}\text { band-lateral- } \\
\text { upper }\end{array}$ & $\begin{array}{l}\text { Microreticulatisporites } \\
\text { type }\end{array}$ & $21-48$ \\
\hline $\begin{array}{l}\text { Anachoropteris } \\
\text { sp. }\end{array}$ & $\begin{array}{l}\text { Galtier \& Phillips } \\
(2014)\end{array}$ & $\begin{array}{l}\text { attached to ultimate } \\
\text { rachial segments }\end{array}$ & sori, (7-9) receptaculum & stalked & oblique lateral & unknown & \\
\hline Radiitheca & $\begin{array}{l}\text { Broumische et al. } \\
\text { (1985) }\end{array}$ & end of veins & $\begin{array}{l}\text { sori, receptaculum } \\
(15-35)\end{array}$ & $\begin{array}{l}\text { sessile or } \\
\text { stalked }\end{array}$ & apical & $\begin{array}{l}\text { Microreticulatisporites } \\
\text { type }\end{array}$ & $35-50$ \\
\hline Kidstoniopteris & $\begin{array}{l}\text { Frojdová et al. } \\
\text { (2017) }\end{array}$ & $\begin{array}{l}\text { pinnule lamina on } \\
\text { pinnule lobes } \\
\text { margin }\end{array}$ & solitary or grouped (5-7) & stalked & semi-equatorial & $\begin{array}{l}\text { Leiotriletes, } \\
\text { Granulatisporites }\end{array}$ & $27-50$ \\
\hline Sturia & $\begin{array}{l}\text { Němejc (1934); } \\
\text { Frojdová (2013) }\end{array}$ & $\begin{array}{l}\text { pinnule lamina close } \\
\text { to pinnule margin }\end{array}$ & solitary & sessile & $\begin{array}{l}\text { incomplete } \\
\text { oblique }\end{array}$ & Apiculatisporites type & $35-53$ \\
\hline Discopteris & $\begin{array}{l}\text { Stur (1883,1885); } \\
\text { Pfefferkorn (1978) }\end{array}$ & from pinnule lamina & sori (to 70 ) & stalked & semi-apical & $\begin{array}{l}\text { Leiotriletes- } \\
\text { Punctatisporites- } \\
\text { Granulatisporites }\end{array}$ & $15-61$ \\
\hline Kidstonia & Zeiller $(1897,1899)$ & $\begin{array}{l}\text { pinnule lamina in } \\
\text { proximal part of } \\
\text { pinnule }\end{array}$ & solitary & sessile & semi-apical & unknown & \\
\hline Boweria & $\begin{array}{l}\text { Kidston }(1911,1923) \text {, } \\
\text { Frojdová et al. } \\
\text { (2017) }\end{array}$ & end of veins & solitary & stalked & lateral & $\begin{array}{l}\text { Leiotriletes, } \\
\text { Granulatisporites }\end{array}$ & $27-58$ \\
\hline Tenchovia & $\begin{array}{l}\text { Pšenička \& Bek } \\
\text { (2004) }\end{array}$ & end of veins & sori (more than 6) & stalked & $\begin{array}{l}\text { bean-shaped } \\
\text { lateral-lower }\end{array}$ & Granulatisporites type & $17-23$ \\
\hline Chansitheca & $\begin{array}{l}\text { Regé (1920), } \\
\text { He et al. }(2015)\end{array}$ & end of veins & sori $(8-20)$ & sessile & oblique & Leiotriletes type & $21-26$ \\
\hline Sturiella & $\begin{array}{l}\text { Scott (1920), } \\
\text { Němejc (1963) }\end{array}$ & $?$ & sori (5) & $\begin{array}{l}\text { sessile or } \\
\text { stalked }\end{array}$ & apical-oblique & unknown & \\
\hline Hymenophyllites & $\begin{array}{l}\text { Goeppert (1836), } \\
\text { Zeiller (1883), } \\
\text { Broumische (1986) }\end{array}$ & $\begin{array}{l}\text { end of veins or } \\
\text { end of lobes }\end{array}$ & sori & stalked & oblique & unknown & \\
\hline Todeopsis & Renault (1896) & $?$ & solitary or grouped & stalked & annulate? & unknown & \\
\hline Pteridotheca & Scott (1909) & pinnule margin & sori (more than 2) & sessile & lateral & unknown & \\
\hline Oligocarpia & Goeppert (1836) & $\begin{array}{l}\text { at the end of the } \\
\text { lateral veins }\end{array}$ & sori $(3-5)$ & stalked & oblique & $\begin{array}{l}\text { Leiotriletes, } \\
\text { Granulatisporites- } \\
\text { type }\end{array}$ & $20-39$ \\
\hline
\end{tabular}

Horizon assemblage point to taxa (e.g. Oligocarpia lindsaeoides, Senftenbergia plumosa) which are known from in situ volcanic ash at the base of the Whestone Horizon (Radnice Member, Kladno Formation), and also to taxa (e.g. Zeilleria hymenophylloides) from upper part of Whestone Horizon consist of laminated mudstone with volcanic admixture where fossil are rare and fragmentary from Radnice, Pilsen or Kladno-Rakovník basins. From this perspective Whetstone Horizon from Stradonice may represent the equivalent of Whetstone Horizon of Pilsen and Kladno-Rakovník basins. Nevertheless, some taxa (e.g. Mixoneura ovata, Annularia stellata) are rather known from younger strata and some taxa (e.g. Lobatopteris miltonii) are typical rather for older strata. However, the flora from this area never been systematically reviewed since Němejc (1930) and therefore some mentioned taxa from Stradonice locality can represent a different species in real.

\section{Conclusion}

Dendraena pinnatilobata is a Pennsylvanian true fern, which is known from Whestone Horizon (Radnice Member, Kladno Formation) the Stradonice locality (Czech Republic) only. D. pinnatilobata pinnae were borne on the rachides of the Anachoropteris robusta-type anatomy. This real organic connection between pinnae/pinnules (including reproductive organs) and rachial anatomy is rare in fossil record. Dendraena pinnatilobata exhibits features similar to some species of several leptosporangiate ferns as Sturia, Tenchovia, Boweria, Kidstoniopteris, Oligocarpia Chansitheca, Sturiella, Todeopsis, Discopteris, Kidstonia, Hymenophyllites and Pteridotheca. Nevertheless, Dendraena is clearly different from those genera having combination of free sessile sporangia irregularly grouped bearing band-lateral-upper type of annulus. Anatomy of those similar genera is still unknown and due to this fact a precise 
systematic comparison cannot be done. Sporangia of Dendraena pinnatilobata has in situ spores of the Microreticulatisporites harrisonii type, described for the first time, and are unique for D. pinnatilobata. Microreticulatisporites in situ spores are known also Radiitheca dobranyana but the general morphology of fertile pinnaea of Dendraena pinnatilobata and Radiitheca dobranyana are quite different. These all facts confirm the unique position and separation of Dendraena pinnatilobata among leptosporangiate ferns. Dendraena pinnatilobata propbably grew in close proximity to the riverside or peatland margins and preferred mineral (clastic) substrates and was probably a part of understorey.

\section{Acknowledgements}

This paper was prepared with the financial support of the Grant Agency of the Czech Republic (GAČR P210-12-2053) and was also partly supported by the research plan of the Institute of Geology of the Czech Academy of Sciences, v.v.i., RVO67985831 and of the Grant Agency of Charles University (GAUK 704216). The authors are very grateful to M. Libertín (National Museum, Prague) for providing access to the specimens in the collections of the institution. We also thank to A. Kalistová (Institute of Geology of the Czech Academy of Sciences) for providing of X-ray powder diffraction investigation. SEM observation was made in Institute of Geology of the Czech Academy of Sciences, v.v.i., Prague by Z. Korbelová, and in Institute of Geology and Palaeontology, Faculty of Science, Charles University in Prague by M. Mazuch, and in the National Museum, Prague by L. Váchová. We would like to thank R. Withers and D. Chaney for English proof reading. We are very grateful to reviewers D. Chaney (Smithsonian Institution, Washington DC) and S. Opluštil (Charles University, Prague) for their comments. We are also grateful to Jöer Schneider for inspirational discussion about sediments from studied area.

\section{References}

BARThel, M. 2016. The Lower Permian (Rotliegend) flora of the Döhlen Formation, Geologica Saxonica 61(2), 105-238.

BERTRAND, P. 1909. Études sur la frond Zygoptéridées. 306 pp. Ph.D. thesis. University of Lille, France.

Broumische, C. 1983. Les Fougères sphénoptéridiennes du Bassin Houiller Sarro-Lorrain (Systematic-Stratigraphie). Publication de la Société Géologique du Nord 10, 1-480.

Broumische, C. 1986. Précisions sur les spores produites par quelques fougères sphénoptéridiennes appartennant aux genres Boweria Kidston, Crossotheca Zeiller, Discopteris Stur, Myriotheca Zeiller et Urnatopteris Kidston. Revue de Paléobiologie 5(2), 231-248.

Broumische, C., Coquel, R., Loboziak, J.P., Loboziak, S. \& ŠETLík, J. 1985. Radiitheca dobranyana n. gen., n. sp., fougère pécoptéridienne du Carbonifère, productrice de spores de type
Microreticulatisporites (Knox) Potonié et Kremp, 145-154. In Dutro, T. JR. \& Pfefferkorn, H.W. (eds) Neuvième Congrès International de Stratigraphie et de Géologie du Carbonifère, Compte Rendu 5.

CoRdA, A.J. 1845. Flora Protogaea, Beiträge zur Flora der Vorwelt. 128 pp. S. Calvary \& Co., Berlin.

Dettmann, M.E. 1963. Upper Mesozoic microfloras from south-eastern Australia. Proceedings of the Royal Society of Victoria 77, 1-148.

DiMichele, W.A. \& Phillips, T.L. 2002. The ecology of Paleozoic ferns. Review of Palaeobotany and Palynology 119, 143-159. DOI 10.1016/S0034-6667(01)00134-8

Galtier, J. \& Phillips, T.L. 1996. Structure and evolutionary significance of Palaeozoic ferns, 417-433. In CAMUS, J.M., Gibby, M. \& Johns, R.J. (eds) Pteridology in Perspective. Royal Botanic Gardens, Kew.

Galtier, J. \& Phillips, T.L. 2014. Evolutionary and ecological perspectives of Late Paleozoic ferns. Part III. Anachoropterid ferns (including Anachoropteris, Tubicaulis, the Sermayaceae, Kaplanopteridaceae and Psalixochlaenaceae). Review of Palaeobotany and Palynology 205, 31-73. DOI 10.1016/j.revpalbo.2014.02.012

GoEPPERT, H.R. 1836. Die fossilen Farrnkräuter (System filicum fossilum). Verhandlungen der Kaiserlichen LeopoldischCarolinischen Akademie der Naturforscher 17(suppl.), $1-486$.

He, X.Z., WANG, S.J. \& WANG, J. 2016. Chansitheca wudaensis (Gleicheniaceae, fern) from the early Permian Wuda Tuff Flora, Inner Mongolia. Palaeoworld 25(2), 199-211. DOI 10.1016/j.palwor.2015.05.011

FrojdovÁ, J. 2013. Leptosporangiate ferns from the Carboniferous basins of Bohemia, selected taxa. $61 \mathrm{pp}$. Master thesis, Faculty of Science, Charles University, Prague, Czech Republic.

Frojdová, J., PŠEnIČKa, J., BeK, J. \& Cleal, J.C. 2017. Revision of the Pennsylvanian fern Boweria Kidston and the establishment of the new genus Kidstoniopteris, Review of Palaeobotany and Palynology 236, 33-58.

DOI 10.1016/j.revpalbo.2016.08.011

Kidston, R. 1911. Les végétaux houillers recueillis dans le Hainaut Belge et se trouvant dans les collections du Musée Royal d'Histoire Naturelle à Bruxelles. Mémoires du Musée royal d'histoire naturelle de Belgique 4(3), Mémoire no. 15, $1-282$.

Kidston, R. 1923. Fossil plants of the Carboniferous rocks of Great Britain. Memoirs of the Geological Survey of Great Britain 2, 275-376.

Knox, E.M. 1950. The spores of Lycopodium, Phylloglossum, Selaginella and Isoetes, and their value in the study of microfossils of Paleozoic age. Transactions of the Botanical Society of Edinburgh 35, 211-357.

Lehnert, M. \& Weigand, A. 2013. A proposal to distinguish several taxa in the Brazilian tree fern Cyathea corcovadensis (Cyatheaceae). Phytotaxa 155(1), 35-49.

DOI 10.11646/phytotaxa.155.1.3

NĚMEJC, F. 1930. Floristické poznámky ku stratigrafii některých 
uhelných pánviček mezi Rokycany a Berounem. Věštník státního geologického ústavu České republiky 6(1), 1-4.

NĚMEJC, F. 1934. On two new sphenopteris fructifications closely allied to Kidston's Boweria (resp. Scott's Pteridotheca) with remarks to some of the already known Palaeozoic fern sporangia. Věstník Královské České Společnosti Nauk, Tř. II, 1934, 1-18.

NĚMEJC, F. 1953a. Úvod do floristické stratigrafie kamenouhelných oblastí ČSR. 173 pp. Nakladatelství Československé akademie věd, Praha.

NĚMEJC, F. 1953b. Taxonomical studies on the fructifications of the Calamitaceae collected in the coal districts of Central Bohemia. Acta Musei Nationalis Pragae, series B, Historia Naturalis 9(1), 1-62.

NĚMEJC, F. 1963. Paleobotanika II. 523 pp. Československá akademie věd, Praha.

OpluštiL, S. 2003. Sedimentation and Paleogeography of the Radnice Member (Duckmantian/Bolsovian) in the Kladno part of the Kladno-Rakovník Basin. Sborník Západočeského Muzea Plzeň, Př́roda 102, 1-83.

OpLuštiL, S. 2005. Evolution of the Middle Westphalian river valley drainage system in central Bohemia (Czech Republic) and its palaeogeographic implication. Palaeogeography, Palaeoclimatology, Palaeoecology 222(3-4), 223-258. DOI 10.1016/j.palaeo.2005.03.016

Opluštil, S., PšEničKa, J., Bek, J., WANG, J., Feng, Z., Libertín, M., ŠIMƯNEK, Z., BUREŠ, J., DRÁBKOVÁ, J. 2014. T0 peat-forming plant assemblage preserved in growth position by volcanic ash-fall: A case study from the Middle Pennsylvanian of the Czech Republic. Bulletin of Geosciences 89(4), 773-818. DOI 10.3140/bull.geosci.1499

Opluštil, S., Schmitz, M., Cleal, J.C. \& MartíneK, K. 2016. A review of the Middle-Late Pennsylvanian west European regional substages and floral biozones, and their correlation tot he Geological Time Scale based on new U-Pb ages. Earth-Science Reviews 154, 301-335.

DOI 10.1016/j.earscirev.2016.01.004

PeŠEK, J. 2001. Středočeské a západočeské svrchnopaleozoické pánve, 10-73. In PeŠEK, J., Holub, V., JARoš, J., Malý, L., Martínek, K., Prouza, V., Spudil, J. \& TÁsLER, R. 2001. Geologie a ložiska svrchnopaleozoických limnických pánví České republiky. Český geologický ústav, Praha.

PeŠEK, J., Holub, V., Jaroš, J., Malý, L., Martínek, K., Prouza, V., SPUdil, J. \& TÁsLER, R. 2001. Geologie a ložiska svrchnopaleozoických limnických pánví České republiky. 243 pp. Český geologický ústav, Praha.

Pešek, J. \& MartíneK, K. 2012. Observations concerning the thickness of rocks eroded between the Cambrian and Bolsovian (= Westphalian C) in Central and Western Bohemia. Folia Musei rerum naturalium Bohemiae occidentalis, Geologica et Paleobiologica 46(1-2), 1-14.

Pettijohn, F.J., Potter, P.E. \& Siever, R. 1973. Sand and Sandstone. 618 pp. Springer Verlag, Berlin. DOI 10.1007/978-1-4615-9974-6
PfefferkoRn, H.W. 1978. Revision der Sphenopteriden Discopteris karwinensis Stur, Discopteris vuellersii Stur und der Gattung Discopteris Stur. Argumenta Palaeobotanica 5, 167-193.

Potonié, R. \& Kremp, G. 1954. Die Gattungen der Paläozoischen Sporae dispersae und ihre Stratigraphie. Geologisches Jahrbuch 69, 111-193.

Potonié, R. \& Kremp, G. 1955. Die Sporae dispersae des Ruhrkarbons ihre Morphographie und Stratigraphie mit Ausblicken auf Arten anderer Gebiete und Zeitabschnitte. Teil I. Palaeontographica 98B, 1-136.

PŠENIČKA, J. 2005. Taxonomy of Pennsylvanian-Permian ferns from coal Basins in the Czech Republic and Canada. 185 pp., 98 pls. Ph.D. thesis, Charles University, Prague, Czech Republic.

PŠEnIČKA, J. \& BEK, J. 2004. Tenchovia bulgarensis gen. et sp. nov., from the Pennsylvanian of the Dobrudzha Coalfield, Bulgaria. Geologica Balcanica 34(1-2), 69-76.

Punt, W., Hoen, P.P., Blackmore, S., Nilsson, S. \& Thomas, A.L. 2007. Glossary of pollen and spore terminology. Review of Palaeobotany and Palynolology 143, 1-81. DOI 10.1016/j.revpalbo.2006.06.008

REGÈ, R. 1920. Note su alcuni vegetali del Carbonifero della Cina. Atti della Società italiana di scienze naturali e del Museo civico di storia naturale in Milano 59(3-4), 183-196.

Remy, R. \& Remy, W. 1957. Durch Mazeration fertiler Farne des Paläozoikums gewonnene Sporen. Paläontologie Zeitschrift 31, 55-65. DOI 10.1007/BF02988963

Renault, B. 1896. Bassin Houiller Permien d'Autun et d'Épinac, Fascicule. IV, Flore Fossile, Deuxième Partie, Texte (Études des Gîtes Mineraux de la France). 578 pp. Imprimerie Nationale, Paris.

Rothwell, G.W. 1987. Complex Paleozoic Filicales in the evolutionary radiation of ferns. American Journal of Botany 74, 458-461. DOI 10.2307/2443822

SChulze, F. 1855. Uber das Vorkommen von wohlerhaltener Zellulose in Braunkohle undSteinkohle. Ber. Kgl. Preuss. Akad. Wiss. 676-678.

ScotT, D.H. 1909. The Present Position of Palaezoic Botany. Progressus Rei Botanicae 1, 139-217.

ScotT, D.H. 1920. Studies in fossil botany. Vol. I: Pteridophyta (3rd edition). 217-239 pp. A. \& C. Black, London. DOI 10.5962/bhl.title.45878

ŠIFTANCOVÁ, E. 2005. Rekonstrukce sedimentárního prostředí a provenience klastického materiálu radnických vrstev stradonického reliktu. Master thesis, Charles University, Prague, Czech Republic.

Smith, A.H.V. \& Butterworth, M.A. 1967. Miospores in the coal seams of the Carboniferous of Great Britain. Special Papers in Palaeontology 1, 1-324.

StÁrková, M., ŠImƯneK, Z. \& DrÁbKová, J. 2016. Geology of Carboniferous outlier between Lísek and Hýskov in paleobotanical and palynological context (Westphalian, Duckmantian). Geoscience Research Reports 49, 215-224.

STUR, D. 1883. Zur Morphologie und Systematik der Culm- und Carbonfarne. Sitzungsberichte der Kaiserlichen Akademie der 
Wissenschaften, Wien, Mathematisch-naturwissenschaftliche Classe 88 (I. Abt.), 633-846.

STuR, D. 1885. Beiträge zur Kenntniss der Flora der Vorwelt. II. Die Carbon-Flora der Schatzlarer Schichten. Abhandlundgen der Kaiserlich-königlichen geologischen Reichsanstalt 11, $1-418$.

TAYlor, T.N., TAYLOR, E.L. \& Krings, M. 2009. Paleobotany: The Biology and Evolution of Fossil Plants (2nd edition). 1253 pp. Academic Press, Amsterdam.

Triplehorn, D.M., Stanton, R.W., Ruppert, L.F. \& Crowley, S.S. 1991. Volcanic ash dispersed in the Wyodak-Anderson coal bed, Powder River Basin, Wyoming. Organic Geo- chemistry 17, 567-575.

DOI 10.1016/0146-6380(91)90119-5

Zeiller, R. 1883. Fructifications de Fougères du Terrain Houiller. Annales Scientifiques de la Nature, 6e série, Botanique 16, 177-209.

ZeILLER, R. 1897. Observation sur quelques Fougères des dépôts houillers d'Asie Mineure. Bulletin de la Société de Botanique de France 44, 195-218.

DOI 10.1080/00378941.1897.10830763

ZeILleR, R. 1899. Étude sur le flore fossile du Bassin houiller d'Heraclee. Mémores de la Société Géologique de la France, Paléontologie 21,1-91. 